\title{
Upper Ordovician conodont biostratigraphy and revised lithostratigraphy and geological map, Akpatok Island, Ungava Bay, Nunavut
}

\begin{tabular}{|r|l|}
\hline Journal: & Canadian Journal of Earth Sciences \\
\hline Manuscript ID & cjes-2017-0145.R1 \\
\hline Manuscript Type: & Article \\
\hline Date Submitted by the Author: & 08-Sep-2017 \\
\hline $\begin{array}{r}\text { Complete List of Authors: } \\
\begin{array}{r}\text { Is the invited manuscript for } \\
\text { consideration in a Special } \\
\text { Issue? : }\end{array}\end{array}$ & Z/A \\
\hline Keyword: & $\begin{array}{l}\text { Upper Ordovician, conodont biostratigraphy, geological map, Akpatok } \\
\text { Island, Ungava Bay }\end{array}$ \\
\hline &
\end{tabular}

\section{SCHOLARONE" \\ Manuscripts}


2 Upper Ordovician conodont biostratigraphy and revised lithostratigraphy

3 and geological map, Akpatok Island, Ungava Bay, Nunavut

4

5

6

7

8

9

10

11

12

13

14

15

16

17 Correspondence author:

18 Shunxin Zhang

19 PO Box 2319, 1106 Inuksugait IV, $1^{\text {st }}$ floor, Iqaluit, Nunavut X0A 0H0, Canada;

20 Phone: (867) 975-4579

21 Fax: (867) 979-0708

22 Email: shunxin.zhang@canada.ca

23

24

25

26

\section{Shunxin Zhang}

Canada - Nunavut Geoscience Office, PO Box 2319, 1106 Inuksugait IV, $1^{\text {st }}$ floor, Iqaluit, Nunavut X0A 0H0, Canada; shunxin.zhang@canada.ca 


\section{Upper Ordovician conodont biostratigraphy and revised lithostratigraphy}

\section{and geological map, Akpatok Island, Ungava Bay, Nunavut}

Shunxin Zhang

\section{Abstract}

Stratigraphic units exposed on Akpatok Island, Ungava Bay, Nunavut, were previously recognized as Boas River and Akpatok formations; their biostratigraphic ages and correlations, in particular the stratigraphic position and age of the organic rich "Boas River" Formation, were largely based on limited data. New detailed field observations have recognized three stratigraphic units, namely the Amadjuak, Akpatok and Foster Bay formations, in which samples from both outcrops and rubble at over 20 localities in four areas. Four Upper Ordovician conodont zones and one unzoned interval are established for the three redefined formations: Belodina confluens and Oulodus velicuspis Interval zones are confined to the exposed Amadjuak Formation and correlated to Edenian and Maysvillian; Amorphognathus ordovicicusPlegagnathus dartoni Concurrent-range Zone occurs with the Akpatok Formation and correlated to lower Richmondian; and Rhipidognathus symmetricus Taxon-range Zone is retained in the

44 Foster Bay Formation and correlated to upper Richmondian; and an "Unzoned Interval" is defined between that last two zones in the lower Foster Bay Formation. The conodont Amorphognathus ordovicicus occurs in both Akpatok and lower Foster Bay formations, and it is

47 also recovered from the bituminous, argillaceous limestone rubble, based on which the stratigraphic position of the previously named "Boas River" Formation is most likely positioned 
50 with geographic information systems (GIS) to establish the thicknesses of the three formations 51 and revise the geologic map of the island.

52 


\section{Introduction}

Akpatok Island is one of the uninhabited Canadian Arctic islands in the Baffin Region of Nunavut, Canada (Fig. 1A). It is the largest island in Ungava Bay, off the northern coast of Quebec where meeting Hudson Strait. With an area of $903 \mathrm{~km}^{2}$, it is predominantly formed by limestone, ringed with steep cliffs that rise 150 to $200 \mathrm{~m}$ above sea level (Fig. 1B). The cliffs are broken in some places by deep ravines allowing access to the flat plateau. The plateau is about $23 \mathrm{~km}$ wide and $45 \mathrm{~km}$ long with the highest elevation about $280 \mathrm{~m}$ in its central area (Fig. 1B).

Geologically, Akpatok Island is one of many Ordovician outliers on the Canadian Shield. It is the only location where the Paleozoic rocks are exposed in Ungava Bay and Hudson Strait; therefore, it plays a key role in understanding the petroleum potential in these offshore areas. However, given the remoteness and isolated location of the island, the logistical challenges have resulted in only limited geological studies to date.

The previous knowledge of the Ordovician stratigraphy of the island resulted from visits by Geological Survey of Canada in 1897 (Bell 1899; Whiteaves 1899), the Oxford University Hudson Strait Expedition in 1931 (Cox 1933a, 1933b, 1933c), and a test hole (Premium Homestead Akpatok F-26 at 60²5’40”N, 68²0’30”W) drilled for hydrocarbons on Akpatok Island in 1969 and the surface survey near the test hole (Workum et al. 1976). Based on these limited data and the previous authors' interpretation, a stratigraphic framework of Akpatok Island and adjacent offshore region, including the Middle Ordovician Ungava Bay and Frobisher Bay formations and the Upper Ordovician Amadjuak, "Boas River” and Akpatok formations, was established, and a geological map of the region was also compiled, without sufficient measured sections and precise age assignments (Sanford and Grant 2000) (Fig. 2A). Although not much of information from the conodont microfossils and outcrop studies supports this 
stratigraphic division and the compiled geological map, these stratigraphic interpretations were used by a recent report (McCracken 2017) on 11 Ordovician conodont samples from Akpatok Island collected by James Gray (University of Montreal) in 1989.

Given these limited earlier studies with uncertain stratigraphic division and age assignments, and stratigraphic relationships between Ungava Bay, Hudson Strait, Hudson Bay and Foxe basins, as well as the implications for hydrocarbon potential, the objectives of this present study are to 1) measure many stratigraphic sections in detail along the deep ravines; 2) sample extensively for conodont microfossils, and document the conodont distribution and establish the conodont zonation; 3) establish more refined Ordovician stratigraphic units and define their thickness to aid regional correlations; 4) determine the correct stratigraphic position of the organic-rich unit; and 5) revise the geological map of Akpatok Island. This present study, therefore, examined over 20 localities in four areas (area I: west of D'Aeth Point; area II: lower reach of Gregson Creek; area III: unnamed creek south of Singer Point; area IV: Cox Ridges) on Akpatok Island (Figs. 1B, 2B, 3A-3D) during two field seasons in 2014 and 2015, and focused on stratigraphic measurements and sampling for conodonts mainly from outcrops, with a few from frost-shattered rubble.

\section{Ordovician stratigraphy of Akpatok Island: the issues, sections, and conodont}

\section{samples}

\section{Ungava Bay Formation}

To replace the Ship Point Formation that was used by Workum et al. (1976), an informal name Ungava Bay Formation was proposed and then elevated to formal status by Sanford and Grant $(1990,2000)$ to identify the Ordovician sandstones and minor carbonate and shales that lie 
100 directly on the Precambrian basement beneath Ungava Bay and eastern Hudson Strait (Fig. 2A).

101 The formation was completely penetrated by the Premium Homestead Akpatok F-26 borehole, 102 and defined at a depth ranging from 172 to $354 \mathrm{~m}$ from the surface, taking the borehole as a type 103 section (Sanford and Grant 2000). However, based on the lithological details from this borehole 104 provided by Workum et al. (1976, fig. 3, appendix), this unit obviously ranges from $146 \mathrm{~m}$ to $105335 \mathrm{~m}$ from the surface. Within the over $180 \mathrm{~m}$ thick Ungava Bay Formation, the only fossil record is a total of 107197 conodont specimens representing seven species and one indeterminate element recovered 108 from the carbonate rocks at a depth between $-264 \mathrm{~m}(867 \mathrm{ft})$ and $-298 \mathrm{~m}(979 \mathrm{ft})$ (Workum et al. 109 1976). This conodont fauna contains Histiodella altifrons Harris represented by two specimens, 110 based on which the Ungava Bay Formation was interpreted as an early Middle Ordovician 111 (middle Whiterockian) age. Except for Oistodus multicorrugatus Harris and Drepanoistodus 112 basiovalis (Sergeeva), this conodont fauna does not show a great similarity to that recovered 113 from Ship Point Formation on the Melville Peninsula, which is referred to as the upper Lower 114 Ordovician by Zhang (2013). Based on the limited conodont data from Akpatok Island, it is 115 uncertain whether 1) the Ungava Bay Formation is younger than the Ship Point Formation on 116 Melville Peninsula, 2) the entire Ungava Bay Formation belongs to early Middle Ordovician, and 117 3) the Ungava Bay Formation spans the Lower-Middle Ordovician boundary. However, 118 considering the latest Early Ordovician age of the Ship Point Formation, this present study 119 temporarily correlates the Ungava Bay Formation to the upper Lower Ordovician and lower 120 Middle Ordovician (Fig. 4). The formation is nowhere exposed onshore; therefore, it was not 121 observed and sampled during this study. 


\section{Frobisher Bay Formation}

124

125

126

127

128

129

130

131

132

133

134

135

136

137

138

139

140

141

142

143

144

145

The Frobisher Bay Formation was informally proposed by Sanford and Grant (1990) to

identify some $15 \mathrm{~m}$ of strata overlying the Ship Point Formation on Melville Peninsula, and then given formal status and correlated to the Middle Ordovician by Sanford and Grant (2000). Based on the conodont fauna recovered from the Frobisher Bay Formation on southern Baffin Island (McCracken 2000) and Melville Peninsula (Zhang 2013), it can be assigned an age of Chatfieldian, Late Ordovician.

The Frobisher Bay Formation is nowhere exposed in the Ungava Bay, Hudson Strait and Foxe Channel, but it is identified in the Premium Homestead Akpatok L-26 borehole at $172 \mathrm{~m}$ to $146 \mathrm{~m}$ below the surface by Sanford and Grant (2000). It does not have fossils to prove whether it correlates to the Frobisher Bay Formation exposed on southern Baffin Island and Melville Peninsula. Without other offshore wells, it is uncertain whether the formation's distribution is the same as that mapped by Sanford and Grant (2000) (Fig. 2A). In the absence of outcrops and conodont data, this study correlates the Frobisher Bay Formation to the early Late Ordovician (Fig. 4) following that on Melville Peninsula (Zhang 2013).

\section{Amadjuak Formation}

The Amadjuak Formation was informally established by Sanford and Grant (1990) for the limestones, shaly limestones and shales that disconformably succeed the Frobisher Bay Formation in the Foxe Basin and adjacent areas of Ungava Bay, Hudson Strait and Foxe Channel. It was raised to formal status by Sanford and Grant (2000).

Sanford and Grant (2000) interpreted that the Amadjuak Formation forms the bedrock surface on the west shore of Akpatok Island, and the formation can be also determined from 
146 cuttings in the Premium Homestead Akpatok L-26 well at depths of 22.9 to $146 \mathrm{~m}$ from the 147 surface. gastropod Maclurites sp., one of the distinctive Fisherites-Maclurites fauna in the Amadjuak Formation on southern Baffin Island (Bolton 2000), and other gastropods and cephalopods from outcrops at an elevation of about $75 \mathrm{~m}$ (locality 6A in Fig. 3B). Therefore, the presence of the Amadjuak Formation on the Akpatok Island is not only at the surface on west coast as Sanford and Grant (2000) interpreted, but also up to a height about $75 \mathrm{~m}$ on the western part of the island.

The Amadjuak Formation on southern Baffin Island and Melville Peninsula was assigned a Late Ordovician Edenian to mid-Maysvillian age (Sanford and Grant 2000; Zhang 2013) based on the typical Fisherites and Maclurites macrofossils (Bolton 2000) and conodont microfossils

157 (McCracken 2000; Zhang 2013). However, there is no fossil record from the Amadjuak 158 Formation (at depths of $-22.9 \mathrm{~m}$ to $-146 \mathrm{~m}$, the Premium Homestead Akpatok L-26 well) 159 determined by Sanford and Grant (2000) to support whether this interval equates to the Amadjuak Formation or part of the Amadjuak Formation on the southern Baffin Island and 161 northeastern Melville Peninsula.

The field observations performed by the present author confirm the presence of the

163 Amadjuak Formation from sea level up to an elevation about $80 \mathrm{~m}$ and $50 \mathrm{~m}$ on the west and east 164 sides of the island, respectively. The sections were measured from the lowest tide level west of 165 the Premium Homestead Akpatok L-26 well up to the lower reach of Gregson Creek southeast of 166 the wellsite (area II in Figs. 1B and 2B), and a total of 13 samples were collected from localities 167 20, 5A, 2A and 6A (Figs. 3B and 5; Tables S1 and S2). In addition, two samples were collected 168 from locality 8A (Figs. 3C and 5; Table S2) on the cliff-top in an unnamed creek south of Singer 
169 170 171 172 173 174 175 176 177 178 179 180 181 182 Island.

Point (area III in Figs. 1B and 2B), and another four from localities 9A and 14 (Fig. 3A and 6; Tables S1 and S2) near the foot of the cliffs west of D'Aeth Point (area I in Figs. 1B and 2B), respectively.

The exposed Amadjuak Formation is composed of hard, light to dark brown, micritic limestone, interbedded with thin layers of chert or chert nodules (Fig. 7A).

\section{"Boas River" Formation}

The "Boas River Shale" was originally named for an "oil shale" unit on Southampton Island, northern Hudson Bay, and its stratigraphic position was placed between the Bad Cache Rapids and Churchill River groups by Heywood and Sanford (1976). It was formally named Boas River Formation by Sanford and Grant (2000). Much more detailed stratigraphic and biostratigraphic studies by Zhang $(2008,2011)$ proved that the "Boas River Shale" is the lower one of the three oil shale intervals in the lower Red Head Rapids Formation on Southampton

Workum et al. (1976) documented a $4.5 \mathrm{~m}$ thick bituminous, brown argillaceous limestone in a stream-cut section along Gregson Creek immediately east of the Premium Homestead Akpatok L-26 wellsite on Akpatok Island, and correlated it to the "Boas River Shale" on Southampton Island. McCracken and Nowlan (1989) reported several Late Ordovician conodont species from two samples from the brown argillaceous limestone collected by G. Macauley and N.J. McMillan in 1986, but could not be certain of their stratigraphic position. This bituminous, argillaceous limestone was assigned to the Boas River Formation, its stratigraphic position was placed between the Amadjuak and Akpatok formations, and its 
191 geographic distribution was illustrated along the east shore of the Akpatok Island (Sanford and 192 Grant 2000, fig. 12) (Fig. 2A).

During a geological reconnaissance on Akpatok Island (Zhang and Mate 2015), the

194 bituminous, argillaceous limestone with abundant graptolites (Figs. 7C-7F), yielding average and maximum total organic carbon (TOC) values of 3.11 and $4.19 \%$, was found at two localities

196 (localities 2A and 3A in area II; Fig. 3B) along lower reach of Gregson Creek, the same creek as 197 section II reported by Workum et al. (1976); however, they were considered as local rubble, 198 rather than outcrops (Zhang and Mate 2015). In addition, much bituminous limestone rubble was 199 also observed around the wellsite (Zhang and Mate 2015; locality 4A in Fig. 3B) which is about $200 \quad 10-20 \mathrm{~m}$ higher than localities $2 \mathrm{~A}$ and $3 \mathrm{~A}$. Based on 1) the macluritid gastropod, the 201 characteristic fossil of the Amadjuak Formation found at an elevation about 75-80 m; and 2) the 202 rubble of the brown bituminous, argillaceous limestone found at elevations between 20 and $30 \mathrm{~m}$ 203 (locality 4A in Fig. 3B), an estimation was made that the organic-rich interval may occur in the 204 lower Amadjuak Formation on Akpatok Island (Zhang and Mate 2015), rather than between 205 Amadjuak and Akpatok formations as Sanford and Grant (1990, 2000) concluded.

206 However, Cox (1933b) described a graptolitic bed at an elevation between 143 and $144 \mathrm{~m}$ 207 (470 and $473 \mathrm{ft}$ ) in a gully in the southern end of the island (most likely in Umiak Cove area), 208 which is a chocolate-coloured limestone with the graptolite Climacograptus inuiti Cox (Cox 209 1933c), a species to be considered as a synonym of Amplexograptus latus (Elles and Wood) by 210 Riva (1988) and others. This species was also found from talus at an elevation of $131 \mathrm{~m}(430 \mathrm{ft})$

211 in section III along Langley Creek by Workum et al. (1976), which may be at the same

212 stratigraphic level as other graptolite species found at an elevation about $10 \mathrm{~m}(30 \mathrm{ft})$ in section 213 II along Gregson Creek of Workum et al. (1976). The conodont and graptolite fauna collected by 
214 the present author from the bituminous, argillaceous limestone rubble (Figs. 7C-7F) at locality

215 3A along Gregson Creek in area II (Fig. 3B), the same Creek as section II reported by Workum

216 et al. (1976) confirms that the bituminous, argillaceous limestone rubble most likely came from

217 the same elevation as the chocolate-coloured limestone described by Cox (1933b), and the

218 bituminous, argillaceous limestone is both topographically and stratigraphically higher than that

219 interpreted by Sanford and Grant (2000) and estimated by Zhang and Mate (2015). However,

220 where is it exactly? Determining the stratigraphic position of the bituminous, argillaceous

221 limestone is critical for its stratigraphic correlation with the organic rich interval in the Hudson

222 Bay and Foxe basins. The conodont and graptolite fauna recovered from the bituminous

223 limestone rubble at locality 3A (Fig. 3B) provides the determination that the term "Boas River"

224 Formation is not deemed appropriate to use on Akpatok Island where the bituminous,

225 argillaceous limestone represents a thin unit, most likely in the lower Foster Bay Formation. This

226 is discussed later in the section on the Upper Ordovician conodont biostratigraphy of Akpatok

227 Island.

228

229

230

231

232

233

234

235

236

\section{Akpatok Formation}

The Akpatok Formation was informally proposed and then raised to formal status for over $240 \mathrm{~m}$ of thin, uniformly bedded limestone exposed in the cliff sections succeeding the Boas River Formation on Akpatok Island by Sanford and Grant (1990, 2000). It was interpreted to underlie much of eastern Hudson Strait and was compared to the Churchill River Group in the Hudson Bay Basin (Sanford and Grant 1990). The highest elevation of Akpatok Island is $281 \mathrm{~m}$ in Cox Ridges area (Figs. 1B and 2B); based on Sanford and Grant (1990, 2000), the island is almost entirely underlain by the Akpatok Formation. However, based on the trilobites and 
237 graptolites discovered by Cox (1933b, 1933c), graptolites by Workum et al. (1976), and

238 gastropods by Zhang and Mate (2015), the lower part of the island belongs to the Amadjuak

239 Formation, but it is unclear where the exact boundary between these two formations is, and

240 whether the Akpatok Formation is the youngest strata on the island.

241

An almost complete section of the Akpatok Formation was found in a creek west of

242 D'Aeth Point (area I in Figs. 1B and 2B) at an elevation between 50 and $120 \mathrm{~m}$. The section was

243 measured and a total of 27 conodont samples were collected along localities 15 and 16 (Figs. 3A

244 and 6; Table S1). The upper part of the formation is also exposed in the uppermost reach of an

245 unnamed creek south of Singer Point (area III in Figs. 1B and 2B) at an elevation between 130

246 and $140 \mathrm{~m}$, where 11 samples were collected from localities 7A and 21 (Figs. 3C and 5; Tables

247 S1 and S2).

248

The lithological expression of the Akpatok Formation is noticeably different from that of

249 underlying Amadjuak Formation; it is formed by grey to dark brownish grey, thin-medium

250 layered limestone, interbedded with thin layered argillaceous limestone (Fig. 7B).

251

\section{Foster Bay Formation}

253 The Foster Bay Formation was informally introduced by Sanford and Grant (1990) for

254 the succession of limestones and dolomitic limestones and associated reefs conformably

255 overlying the Akpatok Formation, representing the youngest Ordovician strata, and succeeded by

256 the lower Silurian Severn River Formation in central Foxe Basin. Later on, it was raised to

257 formal status by Sanford and Grant (2000). However, the Foster Bay Formation was not

258 recognized on Akpatok Island and the adjacent offshore region by Sanford and Grant (2000, fig. 
259 12; Fig. 2A). The field observations and conodont study by the present author confirmed the 260 presence of the Foster Bay Formation on Akpatok Island.

261

262

263

264

265

266

267

268

269

270

271

272

273

274

275

276

277

278

279

280 below).
In the Foxe Basin area, the Foster Bay Formation is not preserved on southern Baffin Island (Zhang 2012), and incompletely exposed on northeastern Melville Peninsula (Zhang 2013). Therefore, it is difficult to compare the Foster Bay Formation to that unit in the Foxe Basin area. Lithostratigraphically, the Foster Bay Formation was correlated to the Red Head Rapids Formation in the Hudson Bay Basin (Sanford and Grant 2000). The Red Head Rapids Formation is well exposed on Southampton Island (Haywood and Sanford 1976; Zhang 2008, 2011) and divided into four units: unit 1 - thin-layered and laminated argillaceous limestone interbedded with oil shale, unit 2 - massive breccia limestone, unit 3 - thick, massive biostromal dolostone and limestone, and unit 4 - thin-bedded limestone with bioherms (Zhang 2008).

In area I, west of D'Aeth Point (Fig. 3A), the rocks exposed on the hill at locality 17 at an elevation between 120 and $150 \mathrm{~m}$ are thin bedded calcareous dolostone (Fig. 7G), where 10 conodont samples were collected (Fig. 6; Table S1); and those at localities 18, 13, 12 and 11 at an elevation between 150 and $220 \mathrm{~m}$ along a creek are thin-medium bedded dolomitic limestone interbedded with massive breccia dolomitic limestone (Fig. 7H), where 17 samples were collected (Fig. 6; Table S1). These rocks are lithologically similar to units 1 and 2, Red Head Rapids Formation on Southampton Island. No outcrops were found at an elevation between 220 $\mathrm{m}$ and the highest point $(281 \mathrm{~m})$ on the Akpatok Island. However, the conodonts collected from three out of five dolostone rubble samples at an elevation between 260 and $281 \mathrm{~m}$ (Fig. 3D; Table S1) confirmed that this interval is part of the Foster Bay Formation (Fig. 6) (see discussion 281 
282

283

284

285

286

287

288

289

290

291

292

293

294

295

296

297

298

299

300

301

302

303

304

\section{The Upper Ordovician conodont biostratigraphy of Akpatok Island}

The earliest study on the Late Ordovician conodonts on Akpatok Island was Workum et

al. (1976) who reported a total of 61 conodont elements collected from four small outcrop samples (totalling less than $1000 \mathrm{~g}$ ) at their sections I and II (along Gregson Creek and Langley

Creek). Most of the conodonts were long-ranged simple cone elements, except for one specimen of Belodina dispansa (Glenister) of Late Ordovician age. Several Late Ordovician conodont species from two samples in the "Boas River shale" were reported by McCracken and Nowlan (1989) with uncertain stratigraphic relationship. Most recently, 38 Late Ordovician conodont species, two elements indeterminate and five species of incertae sedis from 11 samples within an interval (mostly Amadjuak Formation in light of this study) between elevations $-5 \mathrm{~m}$ and $100 \mathrm{~m}$ along Gregson, Langley and Umiak creeks collected by James Gray (University of Montreal) in 1989 were reported by McCracken (2017). In this report, the stratigraphic framework of Sanford and Grant (2000) was followed, and all samples above sea level were located within their Akpatok Formation without support from diagnostic species.

This present report is based on a study of conodonts from 66 conodont-bearing samples out of 90 (each about $3000 \mathrm{~g}$ ) collected at different elevations from the lowest tide level up to the highest point $(281 \mathrm{~m})$ on Akpatok Island, which are confined to the four areas with the best outcrop and rubble potential as shown in Figures 1B, 2B and 3. All the conodonts have excellent preservation with a Colour Alteration Index (CAI) value of 1, indicating minimal thermal alteration in the region (less than $50^{\circ} \mathrm{C}-80^{\circ} \mathrm{C}$ ) (Epstein et al. 1977). The numerical conodont distribution data are presented in Tables S1 and S2, and the conodont stratigraphic distribution on the western and eastern parts of the island are shown in Figures 5 and 6, respectively. In total, over 22000 identifiable conodont specimens plus numerous broken elements are recovered, with 
30537 species representing 22 genera identified, and seven elements indeterminate (Tables S1 and 306 S2). Type and figured specimens are illustrated in Figures 8-10, which are deposited in the 307 National Type Collection of Invertebrate and Plant Fossils, the Geological Survey of Canada 308 (GSC), Ottawa, with assigned curation numbers GSC139109-GSC139212.

311 dartoni Concurrent-range Zone, and Rhipidognathus symmetricus Taxon-range Zone, with an 312 "Unzoned Interval" between the last two zones. The age of the newly identified and revised 313 lithostratigraphic units on Akpatok Island are redefined based on the conodont zones (Fig. 4).

\section{Belodina confluens Interval Zone}

The lower boundary of the Belodina confluens Interval Zone is marked by the lowest

20 near the mouth of Gregson Creek in area II during the lowest tide (Fig. 3B). This lowest occurrence most likely does not represent the first appearance of the species in older strata offshore. The zone is only exposed in about $10 \mathrm{~m}$ strata in the western part of the island at the

321 lowest tide level.

323 (Branson and Mehl) (Figs. 8.20-8.23), Periodon grandis (Ethington) (Figs. 8.16-8.20),

324 Protopanderodus liripipus Kennedy, Barnes and Uyeno (Figs. 10.25-10.26), and species of 325 Panderodus (Table S1). 
329 middle Chatfieldian, Late Ordovician (Fig. 4). In Foxe Basin, the lowest occurrence of this

330 species is close to the base of Frobisher Bay Formation that contains the Appalachignathus

331 delicatulus-Polyplacognathus ramosus conodont fauna (McCracken 2000; Zhang 2013). Without

332 finding this latter fauna on Akpatok Island, the occurrence of $B$. confluens at locality 20 confirms

333 the presence of $B$. confluens Zone, but it is uncertain whether the lower zonal boundary falls

334 within Chatfieldian, or Edenian, or at the boundary of these two stages (Fig. 4).

335

The strata exposed during the lowest tide on the eastern part of the island were not

336

337

338

339 island.

\section{Oulodus velicuspis Interval Zone}

The lower boundary of the Oulodus velicuspis Interval Zone is marked by the lowest occurrence of Oulodus velicuspis (Pulse and Sweet) (Figs. 10.27-10.32) in the sample 05A-01C (Fig. 5) at locality 05A in the lower reach of Gregson Creek in area II (Fig. 3B), and referenced in sample 9A-01C (Fig. 6) at locality 9A near the mouth of a creek in area I, west of D'Aeth Point (Fig. 3A).

Most of the conodont species from the underlying Belodina confluens Interval Zone extended into the Ou. velicuspis Interval Zone, but quite a few new representatives of the NAMP fauna are found in the Ou. velicuspis Interval Zone. Besides the zonal species, it is characterized by several panderodonts with rastrate-element apparatuses, including a belodiniform element Nowlan and McCracken (Fig. 9.16), Culumbodina occidentaiis Sweet (Figs. 9.2-9.3), C. penna 
352 Sweet (Figs. 9.13-9.15), Plegagnathus nelsoni Ethington and Furnish (Figs. 9.11-9.12),

353 Pseudobelodina torta Sweet (Figs. 9.28-9.33) and Ps. v. vulgaris Sweet (Figs. 9.18-9.23). The

354 overall feature of the fauna is similar to that in the Ou. velicuspis Zone in the NAMP (Sweet

355 1988; chart 1), which affirms the correlation between the base of Ou. velicuspis Interval Zone on 356 Akpatok Island and the base of the Ou. velicuspis Zone in the NAMP (Fig. 4). However, these

357 two zones do not span the same stratigraphic intervals; the Ou. velicuspis Interval Zone on 358 Akpatok Island can be correlated to the Ou. velicuspis, Ou. robustus and lower Aphelognathus 359 grandis zones in the NAMP (Fig. 4). This zone is recognized from the outcrops on both sides of 360 the island (Figs. 5 and 6) in the upper Amadjuak Formation.

Amorphognathus ordovicicus - Plegagnathus dartoni Concurrent-range Zone Amorphognathus ordovicicus Branson and Mehl (Figs. 10.1-10.5) is a critical species for

364 global correlation of the Richmondian Stage. Its earliest appearance either marks the base of 365 Richmondian Stage (e.g., Harris et al. 1995) or is slightly higher than the base (Webby et al. 366 2004; Bergström et al. 2009). This present study accepts the latter (Fig. 4). This species is 367 present in the Churchill River Group in Hudson Bay Basin (Zhang and Barnes 2007; Zhang 2011) 368 and the Akpatok Formation in Foxe Basin (McCracken 2000; Zhang 2013), which are correlated 369 to lower Richmondian.

On Akpatok Island, the lowest occurrence of Am. ordovicicus is observed in sample 15-

37101 at the base of Akpatok Formation (Fig. 6) in area I, west of D'Aeth Point (Fig. 3A), which is 372 taken as the base of Am. ordovicicus-Plegagnathus dartoni Concurrent-range Zone. Almost all 373 conodont species that dominated the NAMP fauna in the underlying Oulodus velicuspis Interval 374 Zone survived within this zone. The prominent change in the Am. ordovicicus-Pl. dartoni 
375 Concurrent-range Zone is that Am. ordovicicus, a representative of North Atlantic Province

376 (NAP) fauna (Sweet and Bergström 1974, 1984), invaded the region, indicating a change in

377 environment or climate. Additionally, Plegagnathus dartoni (Stone and Furnish) (Fig. 9.17), a

378 rastrate-element panderodont, is a newcomer, first occurring slightly later than Am. ordovicicus.

379 Plegagnathus dartoni was also used as another indicator of the lower Richmondian Am.

380 ordovicicus Zone in the Hudson Bay area (Zhang 2011). The lowest and the highest occurrences

381 of $P l$. dartoni (samples 15-03 and 16-19) are close to the lower and upper boundary of the

382 Akpatok Formation at localities 15 and 16 in area I, west of D’Aeth Point, respectively (Figs. 3A

383 and 6). Given the co-occurrence of Am. ordovicicus and Pl.dartoni in the Akpatok Formation,

384 this study establishes the Am. ordovicicus-Pl. dartoni Concurrent-range Zone, and correlates it to

385 the lower Am. ordovicicus Zone in the lower Richmondian in the NAP (Fig. 4). The conodont

386 fauna recovered from the samples within an interval between elevations $10 \mathrm{~m}$ and $78 \mathrm{~m}$ in

387 Gregson Creek were assigned to the Akpatok Formation by McCracken (2017), which

388 apparently lacks the support from the Am. ordovicicus and Pl. dartoni fauna.

Normally the two species of Plegagnathus, Pl. dartoni and Pl. nelsoni Ethington and

390 Furnish (Figs. 9.11-9.12) have a similar stratigraphic distribution; therefore, some studies have

391 recognized $P$ l. dartoni as the plegagnathiform element of $P l$. nelsoni (e.g. McCracken 2000). The

392 Am. ordovicicus-Plegagnathus Assemblage in the Akpatok Formation on Melville Peninsula was

393 recognized by Zhang (2013), but is not adopted by this study, because 1) the conodont samples

394 in the Akpatok Formation were collected from rubble and the real stratigraphic distribution of $P l$.

395 dartoni and Pl. nelsoni was unclear on Melville Peninsula (Zhang 2013); and 2) Pl. dartoni and

396 Pl. nelsoni on Akpatok Island have a different lowest occurrence: the former in the lower

397 Akpatok Formation and the latter in the upper Amadjuak Formation, respectively (Fig. 6). 


\section{Unzoned Interval}

The Unzoned Interval is defined for an interval between the highest occurrence of 401 Plegagnathus dartoni and the lowest occurrence of Rhipidognathus symmetricus Branson, Mehl 402 and Branson at locality 17 through lower part of locality 18 in area I, west of D'Aeth Point (Figs. 4036 and 3A), which is in the lower Foster Bay Formation, and possibly includes the uppermost 404 Akpatok Formation that is covered (Fig. 6). The lower Foster Bay Formation is formed by thin 405 bedded calcareous dolostone and massive breccia dolostone, in which the conodont fauna 406 exhibits a dramatic change. Several lineages disappeared including several rastrate-element 407 apparatuses of the Panderodontidae (Belodina, Culumbodina, Plegagnathus and 408 Pseudobelodina), simple cone apparatuses of Protopanderodontidae (Pseudooneotodus and 409 Staufferella), and Belodellida (Walliserodus), as well as ramiform apparatuses of Oulodus and 410 Plectodina. Only a small number of specimens belonging to Amorphognathus ordovicicus, 411 Drepanoistodus suberectus, Panderodus unicostatus (Branson and Mehl), and Paroistodus?

412 nowlani Zhen, Webby and Barnes are found in the upper part of this interval, but there are 413 almost no conodonts in rest of the interval (Fig. 6; Table S1).

414 The stratigraphic distribution of Am. ordovicicus and R. symmetricus overlaps in the 415 lower Red Head Rapids Formation on Southampton Island, which is assigned to the lower $R$. 416 symmetricus Zone (Zhang 2011). Although Amorphognathus ordovicicus extends into the lower

417 Foster Bay Formation on Akpatok Island, R. symmetricus is not found in this interval (Fig. 6).

418 Without $R$. symmetricus, this part of the stratigraphy is assigned as an Unzoned Interval, but it 419 probably correlates to the lower $R$. symmetricus Taxon-range Zone (see discussion below) based 420 on lithology. 
Rhipidognathus symmetricus Taxon-range Zone

The lower boundary of Rhipidognathus symmetricus Taxon-range Zone is marked by the

424 lowest occurrence of $R$. symmetricus (Figs. 10.21-10.24) in sample 18-08 (Fig. 6) at locality 18

425 in area I, west of D'Aeth point (Fig. 3A). The highest occurrence of this species is almost at the

426 highest point $(281 \mathrm{~m})$ of the island, which is the rubble sample 19-02 at locality 19 in area VI,

427 close to Cox Ridges (Fig. 3D). Therefore, this highest occurrence may mark the upper boundary

428 of the $R$. symmetricus Taxon-range Zone, but it is equally possible that the upper part of the zone

429 has been eroded off. Between the lowest and highest occurrence of the zonal species, only four

430 out of 15 samples produce conodont elements, all with low abundance and diversity (Table S1).

431 Only three species, namely $R$. symmetricus, Belodina confluens and Panderodus unicostatus, are

432 present. Given the rarity of $R$. symmetricus in the region, it is possible that this zone extends

433 down to the underlying Unzoned Interval.

It has been documented that $R$. symmetricus has a relatively wide stratigraphic range from

435 Edenian to late Richmondian in the NAMP (Sweet 1984, 1988). However, this species is

436 restricted in a much narrower stratigraphic interval in the Hudson Bay Basin (Zhang and Barnes

437 2007; Zhang 2011), Foxe Basin (Zhang 2013) and southern Ontario (Zhang et al. 2011) than

438 elsewhere in the NAMP. R. symmetricus is limited within the Red Head Rapids Formation in the

439 Hudson Bay Basin (Zhang and Barnes 2007; Zhang 2011), the Foster Bay Formation in the Foxe

440 Basin (Zhang 2011), and the upper Georgina Bay Formation in southern Ontario (Zhang et al.

441 2011). These rock units have a common feature that they are composed of thin bedded

442 calcareous dolostone or thin bedded dolomitic limestone and massive breccia dolostone or

443 bioherms; additionally they are also as unproductive of conodonts as the Foster Bay Formation 
444 on Akpatok Island. This is an indication of the shallowest and restricted environment (Sweet 445 1988).

Given the co-occurrence of Aphelognathus cf. A. divergens Sweet and Rhipidognathus

447 symmetricus, the R. symmetricus Zone in the Red Head Rapids Formation on Southampton

448 Island and R. symmetricus-A. cf. A. divergens Assemblage in the Foster Bay Formation on

449 Melville Peninsula were correlated to the $A$. divergens Zone in the upper Richmondian of NAMP

450 (Zhang 2011, 2013). This correlation is followed in this present study (Fig. 4).

\section{The stratigraphic position and the age of organic-rich bituminous, argillaceous limestone}

As noted earlier, the present author did not find a $4.5 \mathrm{~m}$ thick bituminous, brown argillaceous limestone in a stream-cut section immediately east of the Premium Homestead Akpatok L-26 wellsite on Akpatok Island as reported by Workum et al. (1967), but the lithology was seen as rubble at localities $2 \mathrm{~A}$ and $3 \mathrm{~A}$ in the lower reach of Gregson Creek in area II (Fig.

457 3B), the same creek as that of Workum et al. (1976). One bituminous, argillaceous limestone rubble sample (SZ15-22-01; Table S1) was processed for conodonts and yielded (number of

459 specimens in brackets) Amorphognathus ordovicicus (10), Belodina confluens (6),

Coelocerodontus trigonius Ethington (35) Drepanoistodus suberectus (Branson and Mehl) (74),

461 Panderodus feulneri (Glenister) (253), Paroistodus? nowlani (134), Plectodina tenuis (Branson

462 and Mehl) (5), Pseudooneotodus beckmanni (Bischoff \& Sannemann) (3), and Scabbardella sp. 463 (55). 
467 Formation on Akpatok Island (Figs. 5 and 6). Am. ordovicicus has a relatively shorter

468 stratigraphic range in the Akpatok and lower Foster Bay formations. Therefore, the bituminous,

469 argillaceous limestone rubble sample yielding Am. ordovicicus may be from either the upper

470 Akpatok Formation or lower Foster Bay Formation. Considering the oil shale intervals in the

471 lower Red Head Rapids Formation on Southampton Island that contain both Am. ordovicicus and

472 R. symmetricus (Zhang 2011), the bituminous, argillaceous limestone rubble on Akpatok Island

473 is most likely from the lower Foster Bay Formation.

474

Additionally, the graptolites discovered from the bituminous, argillaceous limestone

475 rubble confirm this correlation. A "chocolate-coloured limestone" band yielding the graptolite

476 Amplexograptus latus (Elles and Wood) (= Climacograptus inuiti Cox described by Cox (1933c)

477 occurs at an elevation between 143 and $144 \mathrm{~m} \mathrm{(470} \mathrm{and} 473 \mathrm{ft})$ in a creek (most likely Umiak

478 Creek) at the southern end of the island (Cox 1933b). This species was not found in the

479 bituminous, argillaceous limestone rubble that yields graptolites Anticotia? decipiens (Riva) and

480 Rectograptus socialis (Lapworth) (identified by Riva 2017; author's collection). On Anticosti

481 Island, the former is associated with A. latus in the graptolite Paraorthograptus prominens Zone

482 (Riva 1988), and the latter's highest occurrence is in the lower part of the zone (McLaughlin et al.

483 2016). Therefore, the bituminous, argillaceous limestone rubble discovered by this study can be

484 correlated with the "chocolate-coloured limestone" band of Cox (1933b), which is within the

485 stratigraphic level of lower Foster Bay Formation recognized by this study (Fig. 6).

486 Thus, the stratigraphic position of the organic-rich bituminous, argillaceous limestone on

487 Akpatok Island is in the lower Foster Bay Formation, and probably within the Unzoned Interval,

488 rather than between the Amadjuak and Akpatok formations as inferred by Sanford and Grant

489 (2000) (Fig. 4). Regionally, taking graptolites into account, the organic-rich bituminous, 
490 argillaceous limestone on Akpatok Island may be related to the lower oil shale interval of the

491 three, yielding the graptolite Amplexograptus latus (identified by Riva 2017; the author's

492 collection), of the Red Head Rapids Formation on Southampton Island (Zhang 2008); and it has

493 an age of late Richmondian, Late Ordovician based on the conodonts and graptolites. Therefore,

494 the present study does not consider "Boas River" Formation as an appropriate stratigraphic unit

495 on Akpatok Island.

496

Topographically, the organic-rich bituminous, argillaceous limestone is distributed at an

497 elevation about $140 \mathrm{~m}$, instead of at the foot of the cliff along east coast as illustrated by Sanford

498 and Grant (2000) (Fig 2A). Additionally, the $4.5 \mathrm{~m}$ thick bituminous, brown argillaceous

499 limestone documented by Workum et al. (1967) is most likely a pile of rubble by the stream

500 (locality 3A in Fig. 3B) where the bituminous, argillaceous limestone rubble sample described

501 herein was collected.

502

503

504

505

506

507

508

509

510

511

512

\section{Combining conodont data with GIS technology to revise the geological map}

ArcGIS Map provides contour lines at $10 \mathrm{~m}$ intervals for Akpatok Island (Fig. 3). The

Ordovician rocks on Akpatok Island only slightly dip eastward; therefore, the contour lines and elevations provided by GIS can be used to define the thickness of stratigraphic units, and revise the existing geological map by combining with paleontologic and stratigraphic data. The prerequisite of this approach is that the known localities have reliable coordinate data, zonal fossils, and (or) exposed stratigraphic boundaries between different units (Zhang 2013).

\section{Defining the thickness of different stratigraphic units}

As noted earlier, the rocks rising abruptly from the sea to form Akpatok Island were assigned to mostly one unit, the Akpatok Formation, by Sanford and Grant (2000); the present 
513 detailed field observations and conodont study have identified three formations within this

514 sequence. The rocks on Akpatok Island are either very well exposed on the inaccessible vertical

515 cliffs surrounding the island, or scattered along streams inland, which make it difficult to

516 measure the exact thickness of different stratigraphic units. However, the contour lines and

517 elevation data on ArcGIS map provide an ideal tool to accomplish this task.

518 Amadjuak Formation: The lower boundary of Amadjuak Formation is under the low tide

519 level; the upper boundary can be recognized by either the appearance of thin bedded argillaceous

520 limestone, the typical lithology of the overlying Akpatok Formation, or the lowest occurrence of

521 Amorphognathus ordovicicus, the characteristic species present throughout the Akpatok

522 Formation, which is close to the $50 \mathrm{~m}$ contour line at locality 15, area I, west of D'Aeth Point

523 (Figs. 3 and 6). In the western part, the highest elevation where samples lack Am. ordovicicus is

524 between the $70 \mathrm{~m}$ and $80 \mathrm{~m}$ contour lines. Therefore, the exposed Amadjuak Formation is about

$52570-80 \mathrm{~m}$ on western side and $50 \mathrm{~m}$ on the eastern side, respectively, because of the eastward

526 dipping strata.

527 Akpatok Formation: The lower boundary of the Akpatok Formation equates to the upper

528 boundary of the Amadjuak Formation (50 m contour line) at locality 15, area I, west of D'Aeth

529 Point (Figs. 3 and 6). The boundary between the Akpatok Formation and the overlying Foster

530 Bay Formation is not exposed in the studied areas, but most likely occurs between the $100 \mathrm{~m}$ and

$531120 \mathrm{~m}$ contour lines in area I, west of D'Aeth Point (Fig. 6). In this area, the typical thin bedded

532 dolostone appears near the $120 \mathrm{~m}$ contour line; therefore, the thickness of the Akpatok Formation

533 is between $50 \mathrm{~m}$ and $70 \mathrm{~m}$ on the eastern part of the island. In area III, along an unnamed creek

534 south of Singer Point, the highest occurrence of Plegagnathus dartoni is between the $130 \mathrm{~m}$ and

$535140 \mathrm{~m}$ contour lines, and the highest sample lacking Amorphognathus ordovicicus is between 70 
$536 \mathrm{~m}$ and $80 \mathrm{~m}$ contour lines; therefore, the thickness of the formation is about $60 \mathrm{~m}$ in this area.

537 Thus, the estimations made in both areas I and III are close to $60 \mathrm{~m}$ for the thickness of the 538 Akpatok Formation.

539 Foster Bay Formation: All the rocks above the Akpatok Formation belong to the Foster 540 Bay Formation. Its thickness can be either above the $140 \mathrm{~m}$ contour line based on the estimation 541 in area III, or above the $120 \mathrm{~m}$ contour line based on the estimation in area I. However, the 542 highest point, $281 \mathrm{~m}$, in area IV close to Cox Ridges is in the central island, where the lower 543 boundary of the Foster Bay Formation is most likely at an average contour value between area I 544 and III. Thus, the thickness of the Foster Bay Formation is about $150 \mathrm{~m}$.

545

546 Revising the geological map of Akpatok Island

547 The lower and upper boundaries of the Akpatok Formation are important in modifying 548 the geological map of Sanford and Grant (2000) (Fig. 2A). Based on the discussion earlier, these 549 boundaries are close to the $50 \mathrm{~m}$ and $120 \mathrm{~m}$ contour lines on the eastern side of the Island (Figs. $5503 \mathrm{~A}$ and 6 ), and $70 \mathrm{~m}$ and $140 \mathrm{~m}$ on the western part of the island (Figs. 3C and 5). Using these 551 contour lines as the boundaries between the Amadjuak and Akpatok formations and between the 552 Akpatok and Foster Bay formations, a new geological map of Akpatok Island is completed (Fig. 553 2B). Thus, most of surface area on Akpatok Island is covered by the Foster Bay Formation (Fig. 554 2B), rather than the Akpatok Formation as mapped by Sanford and Grant (2000) (Fig. 2A). A 555 cross section from A through A' to A" shown in Figure 2B is illustrated in Fig. 2C, which clearly 556 shows that both Amadjuak and Akpatok formations are exposed in the high cliffs that surround 557 the island. 


\section{Summary}

560

561

562

563

564

565

566

567

568

569

570

571

572

573

574

575

576

577

578

579

580

581

- The strata exposed on Akpatok Island are recognized as Upper Ordovician upper Amadjuak, Akpatok and Foster Bay formations.

- Thirty-seven conodont species representing 22 genera, with seven elements indeterminate, are identified among 22000 identifiable conodont specimens from 66 conodont-bearing samples at over 20 localities in four areas on Akpatok Island, which stratigraphically covers the newly recognized three formations.

- Four Upper Ordovician conodont zones, namely Belodina confluens and Oulodus velicuspis Interval zones, Amorphognathus ordovicicus-Plegagnathus dartoni Concurrent-range Zone, and Rhipidognathus symmetricus Taxon-range Zone are newly established, and an "Unzoned Interval" is defined between that last two zones within the exposed Upper Ordovician sequence. The B. confluens and Ou. velicuspis Interval zones are confined to the exposed Amadjuak Formation and correlated to the upper B. confluens, Ou. velicuspis and $\mathrm{Ou}$. robustus zones throughout an interval of Edenian and Maysvillian; the Am. ordovicicus-Pl. dartoni Concurrent-range Zone occurs in the Akpatok Formation and is correlated to the lower Am. ordovicicus Zone, lower Richmondian; the "Unzoned Interval" and $R$. symmetricus Taxon-range Zone are present in the Foster Bay Formation and related to the Aphelognathus divergens Zone, upper Richmondian. Except for the fauna in the Am. ordovicicus-Pl. dartoni Concurrent-range Zone partially having a relationship to the North Atlantic Province (NAP) fauna, those in the other zones are mostly related to the North American Midcontinent Province (NAMP) faunas.

- The occurrence of conodont Amorphognathus ordovicicus in the outcrops of both the Akpatok and lower Foster Bay formations and in the bituminous, argillaceous limestone 
582

583

584

585

586

587

588

589

590

591

592

593

594

595

596

597

598

599

600

601

602

603

604

605

rubble, as well as graptolite Anticotia? decipiens and Rectograptus socialis, indicate that the stratigraphic position of the thin bituminous, argillaceous limestone unit is most likely in the lower Foster Bay Formation, rather than between the Amadjuak and Akpatok formations, and its topographic position is about $140 \mathrm{~m}$ above sea level, instead of on the shore.

- The field observation, paleontological data and stratigraphic analysis on Akpatok Island combined with GIS technology enable accurate calculations of the thickness of different lithostratigraphic units and substantially revising the geological map of Akpatok Island.

\section{Acknowledgements}

This study is part of the Hudson-Ungava Project under Natural Resource Canada (NRCan), Earth Science Sector's (ESS) Geo-mapping for Energy and Mineral Program 2 (GEM2), and it is financially supported by both GEM-2 and the Canada-Nunavut Geoscience Office (CNGO). Logistic support in the field was provided by the Polar Continental Shelf Project. Many thanks are extended to D. Lavoie (Geological Survey of Canada (GSC) Quebec) for his organization of the project and participation in the fieldwork and to J. Riva (GSC Quebec) for his identification of graptolite fossils. Sincere thanks go to the Inuit from Kuujjuaq, northern Quebec for their field assistance, to H. Taylor and L. Tingley for their hard work in processing samples at the conodont labs at GSC Vancouver and GSC Calgary, respectively, and to P. Hunt (GSC

Ottawa) for her assistance in taking scanning electron microscopy images. Particular thanks go to C.R. Barnes (University of Victoria) for his comments on the first draft of the manuscript, to M. Orchard (GSC Vancouver) for acting as ESS internal scientific reviewer, to A.D. McCracken (GSC Calgary) and G.L. Albanesi (Universidad Nacional de Córdoba) for acting as external scientific reviewers, and to A. Polat, B. Pratt and D. Regier for their editorial assistance from the journal. 
607

608

609

610

611

612

613

614

615

616

617

618

619

620

621

622

623

624

625

626

627

628

629

\section{References}

Albanesi, G.L., and Ortega G. 2016: Conodont and graptolite biostratigraphy of the Ordovician System of Argentina. Stratigraphy and Timescales, 1: 61-121.

Barnes, C.R., Rexroad, C.B., and Miller, J.F. 1973: Lower Paleozoic conodont

provincialism. In Symposium on Conodont Paleozoology. Edited by F.H.T. Rhodes. The Geological Society of America, Special Paper 141, pp.156-190.

Barrass, R. 1954: Graptolites from Anticosti Island. Quarterly Journal of the Geological Society of London, 110: 55-74.

Bell, R. 1899: Contribution to Paleontology. Geological Survey of Canada Annual Report, New Series 10 , pp. $75 \mathrm{~A}-83 \mathrm{~A}$.

Bergström, S.M., Chen, X., Gutiérrez-Marco, J.C., and Dronov, A. 2009. The new chronostratigraphic classification of the Ordovician System and its relations to major regional series and stages and to $\delta^{13} \mathrm{C}$ chemostratigraphy. Lethaia, 42(1): 97-107.

Bolton, T.E. 2000. Ordovician megafauna, southern Baffin Island, Nunavut. In geology and paleontology of the southeast Arctic Platform and southern Baffin Island, Nunavut. Edited by A.D. McCracken and T.E. Bolton. Geological Survey of Canada Bulletin 557, pp. 39-157.

Cooper, R.A., and Sadler, P.M. 2012. Chapter 20. The Ordovician Period. In The Geological Time Scale 2012. Edited by F.M. Gradstein, J.G. Ogg, M.D. Schmitz, and G.M. Ogg. Elsevier, Amsterdam (ebook). pp. 489-523.

Cox, I. 1933a: Rejuvenation on Akpatok Island: Topographical Unconformity in North-Eastern Canada. Geological Magazine, 70: 67-83.

Cox, I. 1933b. Richmondian trilobites from Akpatok Island. Geological Magazine, 70: 359-373. 
630 631

632

633

634

635

636

637

638

639

640

641

642

643

644

645

646

647

648

649

650

651

652

Cox, I. 1933c. On Climacograptus inuiti sp. nov. and its Development. Geological Magazine, 70: $1-19$.

Epstein, A.G., Epstein, J.B. and Harris, L.D. 1977. Conodont color alteration-An index to organic metamorphism. U.S. Geological Survey Professional Paper 995, 27 pp.

Harris, A.G., Dumoulin, J.A., Repetski, J.E., and Carter, C. 1995. Correlation of Ordovician rocks of Northern Alaska. In Ordovician odyssey. Edited by J.D. Cooper. Society for Sedimentary Geology, Pacific Section. pp. 21-26.

Heywood, W.W., and Sanford, B.V. 1976. Geology of Southampton, Coats and Mansel Islands, District of Keewatin, Northwest Territories. Geological Survey of Canada, Memoir 382, $35 \mathrm{p}$.

McCracken, A.D. 2000. Middle and Late Ordovician conodonts from the Foxe Lowland of southern Baffin Island, Nunavut. Geological Survey of Canada Bulletin 557, pp. 159-216.

McCracken, A.D. 2017. Report on 11 Ordovician conodont samples from Akpatok Island, Nunavut collected by James Gray (University of Montreal) in 1989, NTS 25B/5 and 25C/8. Geological Survey of Canada Paleontological Report 1-ADM-2017, 26 pp.

McCracken, A.D., and Nowlan, G.S. 1989. Conodont paleontology and biostratigraphy of Ordovician carbonates and petroliferous carbonates on Southampton, Baffin, and Akpatok islands in the eastern Canadian Arctic. Canadian Journal of Earth Sciences, 26(10): 1880-1903.

McLaughlin, P.I., Emsbo, P., Desrochers, A., Bancroft, A., Brett, C.E., Riva, J.F., Premo, W., Neymark, L., Achab, A., Asselin, E., and Emmons, M.M. 2016: Refining 2 km of Ordovician chronostratigraphy beneath Anticosti Island utilizing integrated chemostratigraphy. Canadian Journal of Earth Sciences, 53(8): 865-874. 
653 Riva, J. 1988: Graptolites at and below the Ordovician-Silurian boundary on Anticosti Island,

654 Canada. Bulletin of the British Museum (Natural History), Geology, 43: 221-237.

655 Sanford, B.V., and Grant, A.C. 1990: New findings relating to the stratigraphy and structure of 656 the Hudson Platform. Geological Survey of Canada Current Research, Part D, Paper 90657 1D, pp. 17-30.

658 Sanford, B.V., and Grant, A.C. 2000: Geological framework of the Ordovician system in the 659 southeast Arctic Platform, Nunavut. In geology and paleontology of the southeast Arctic 660 661 662 663 664 665 666 667 668 669 670

671 Sweet, W.C. and Bergström, S.M. 1984. Conodont provinces and biofacies of the Late Ordovician. Geological Society of America Special Paper 196, pp. 69-87.

673 Webby, B.D., Cooper, R.A., Bergström, S.M., and Paris, F. 2004. Stratigraphic framework and 674 time slices. In The great Ordovician Biodiversification Event. Edited by B.D. Webby, F. 675 Paris, M.L. Droser, and I.G. Percival. Columbia University Press, New York. pp. 41-47. 
676 Whiteaves, J.F. 1899: Recent discovery of rocks of the age of the Trenton formation at Akpatok

677 Island, Ungava Bay, Ungava. American Journal of Science, 7 (42), 433-434.

678 Workum, R.H., Bolton, T.E., and Barnes, C.R. 1976. Ordovician geology of Akpatok Island, 679 Ungava Bay, District of Franklin. Canadian Journal of Earth Sciences, 13: 157-178.

680

681

682

683

684

685

686

687

688

689

690

691

692

693

694

695

696

697

698

Zhang, S. 2008: New insights into Ordovician oil shales in Hudson Bay Basin: their number, stratigraphic position, and petroleum potential. Bulletin of Canadian Petroleum Geology, 56 (4): 300-324.

Zhang, S. 2011: Late Ordovician conodont biostratigraphy and redefinition of the age of oil shale intervals on Southampton Island. Canadian Journal of Earth Sciences, 48: 619-643.

Zhang, S. 2012. Ordovician stratigraphy and oil shale, southern Baffin Island, Nunavut preliminary field and post-field data. Geological Survey of Canada, Open File 7199, 26 p.

Zhang, S. 2013. Ordovician conodont biostratigraphy and redefinition of the age of lithostratigraphic units on northeastern Melville Peninsula, Nunavut. Canadian Journal of Earth Sciences, 50 (8): 808-825.

Zhang, S., and Barnes, C.R. 2007. Late Ordovician - Early Silurian conodont biostratigraphy and thermal maturity, Hudson Bay Basin. Bulletin of Canadian Petroleum Geology, 55 (3): $179-216$.

Zhang, S., and Mate, D.J. 2015. Geological reconnaissance for Ordovician stratigraphy and petroleum potential, Akpatok Island, Nunavut. In Summary of Activities 2014, CanadaNunavut Geoscience Office, pp. 79-88.

Zhang, S., Tarrant, G.A., and Barnes, C.R. 2011. Upper Ordovician conodont biostratigraphy and the age of the Collingwood Member, southern Ontario, Canada. Canadian Journal of Earth Sciences, 48: 1497-1522. 
700

701

702

703

704

705

706

707

708

709

710

711

712

713

714

715

716

717

718 719 respectively.

720

721

722 locations. respectively.

\section{Figure Captions}

Figure 1. A: Location of Akpatok Island in Ungava Bay; B: elevation map of Akpatok Island, showing the studied areas (red rectangles) and locality numbers.

Figure 2. Geological maps of Akpatok Island. A: modified from Sanford and Grant (2000); B: new map by this study based on the paleontological and stratigraphical data combined with GIS data, showing the studied areas (red rectangles) and locality numbers; C: stratigraphic cross section from A through $A^{\prime}$ to A" in map B.

Figure 3. Detailed geological maps in four selected studied areas on Akpatok Island with sampling localities. A: area I, west of D’Aeth Point; B: area II, lower reach of Gregson Creek; C: area III, unnamed creek south of Singer Point; D: area IV, Cox Ridges. See Figures 1 and 2 their

Figure 4. Ordovician stratigraphy on Akpatok Island and its correlation with the Ordovician chronostratigraphic and biostratigraphic framework adopted from Cooper and Sadler (2012) (* in North Atlantic conodont zonation is base on Albanesi and Ortega (2016)). Shaded area represents the stratigraphy exposed on Akpatok Island and conodont zones lithostratigraphic units recognized herein.

Figure 5. Conodont distribution at different elevations in areas II and III on the western side of Akpatok Island. The numbers before and after hyphen are locality and sample numbers,

Figure 6. Conodont distribution at different elevations in areas I and IV on the eastern side and central of Akpatok Island. The numbers before and after hyphen are locality and sample numbers, 
723 Figure 7. Typical lithology of Upper Ordovician units on Akpatok Island. A: Amadjuak

724 Formation brown micritic limestone, interbedded with thin layers of chert and chert nodules that

725 are circled with white at locality 14, area I; B: Akpatok Formation grey to dark brownish grey,

726 thin-medium bedded limestone, interbedded with thin bedded argillaceous limestone at locality

727 21, area III; C-F: brown argillaceous, bituminous limestone rubble at locality 2 and 3, area II; E:

728 an enlargement of a spot marked by a hammer on the left corner in D; F: enlargement marked by

729 a hammer on the right in D and where the graptolites are found; G and H: Foster Bay Formation

730 thin bedded dolomitic limestone $(\mathrm{G})$ and thin-medium bedded dolomitic limestone interbedded

731 with massive breccia dolomitic limestone $(\mathrm{H})$ at localities 17 and 18, area I.

732

733 Figure 8. Late Ordovician conodonts and incertae sedis

734 1. Milaculum ethinclarki Müller (non-conodont) (×60) from SZ15-16-11, Akpatok Formation;

735 upper view, GSC139109.

736 2. Milaculum sp. (non-conodont) $(\times 60)$ from SZ15-16-12, Akpatok Formation; upper view,

737 GSC139110.

738 3-7. Walliserodus curvatus (Branson and Branson) $(\times 70)$ from SZ14-05-01C, Amadjuak

739 Formation; 3, inner lateral view of unicostatiform element, GSC139111; 4, inner lateral view of

740 curvatiform element, GSC139112; 5 and 6, lateral and lateral-posterior view of dyscritiform

741 element, GSC139113; 7, inner lateral view of multicostatiform element, GSC139114.

742 8-11. Panderodus breviusculus Barnes (×35) from SZ15-16-18, Akpatok Formation; 8 and 9,

743 inner and outer lateral views of asymmetric graciliform element, GSC139115; 10 and 11, inner

744 and outer lateral views of subsymmetric graciliform element, GSC139116. 
745

746

747

748

749

750

751

752

753

754

755

756

757

758

759

760

761

762

763

764

765

766

767

12-16. Panderodus feulneri (Glenister) $(\times 85)$ from SZ15-22-01 (bituminous, argillaceous limestone rubble), Foster Bay Formation (?); 12, inner lateral view of truncatiform element, GSC139117; 13, inner lateral view of compressiform element, GSC139118; 14, inner lateral view of tortiform element, GSC139119; 15, inner lateral view of arcuatiform element, GSC139120; 16, inner lateral view of asymmetric graciliform element, GSC139121.

17-19. Belodina confluens Sweet $(\times 55)$ from SZ-15-04, Akpatok Formation; 17. outer lateral view of compressiform element, GSC139122; 18, outer lateral view of grandiform element, GSC139123; 19, inner lateral view of eobelodiniform element, GSC139124.

20-23. Drepanoistodus suberectus (Branson and Mehl) (×35) from SZ15-15-06, Akpatok Formation; 20, inner lateral view of curvatiform element, GSC139125; 21, inner lateral view of homocurvatiform element, GSC139126; 22, lateral view of suberectiform element, GSC139127; 23, inner lateral view of oistodiform element, GSC139128.

24-25. Staufferella lindstroemi (Ethington and Schumacher) from SZ14-02A-02C, Amadjuak Formation; $24(\times 60)$, inner lateral view of asymmetricform element, GSC139129; $25(\times 50)$, posterior view of symmetricform element, GSC139130.

26. Pseudooneotodus mitratus (Moskalenko) $(\times 90)$ from SZ15-16-01, Akpatok Formation; upper view, GSC139131.

27. Pseudooneotodus beckmanni (Bischoff and Sannemann) (×65) from SZ15-16-01, Akpatok Formation; upper view, GSC139132.

28-29. N. Gen. A n. sp. A McCracken $(\times 70)$ from SZ15-21-07, Akpatok Formation; lateral and posterior views, GSC139133.

30-34. Panderodus liratus Nowlan and Barnes $(\times 45)$ from SZ15-15-03, Akpatok Formation; 30, inner lateral view of arcuatiform element, GSC139134; 31, outer lateral view of truncatiform 
768 element, GSC139135; 32, inner lateral view of asymmetrical graciliform element, GSC139136;

76933 , outer lateral view of compressiform element, GSC139137; 34, inner lateral view of

770 subsymmetric graciliform element, GSC139138.

771 35-36. Coelocerodontus trigonius Ethington $(\times 67)$ from SZ15-22-01, Akpatok Formation; 35 ,

772 posterior view of symmetric triangular element, GSC139139; 36, posterior view of asymmetric

773 triangular element, GSC139140.

774 37-40. Zanclodus sp. (×50) from SZ15-16-04, Akpatok Formation; 37 and 38, inner and outer

775 lateral views of low-based element, GSC139141; 39 and 40, inner and outer lateral views of

776 high-based element, GSC139142.

777 41-42. Staufferella n. sp. A McCracken (×75); 41 from SZ15-16-04, Akpatok Formation, 778 posterior view of symmetric element, GSC139143; 42 from SZ15-16-01, Akpatok Formation, 779 posterior view of asymmetric element, GSC139144.

780 43-49. Panderodus unicostatus (Branson and Mehl) (×53); from SZ15-21-02, Amadjuak

781 Formation; 43, inner lateral view of arcuatiform element, GSC139145; 44, inner lateral view of 782 tortiform element, GSC139146; 45, lateral view of aequitiform element, GSC139147; 46, inner 783 lateral view of compressiform element, GSC139148; 47, outer lateral view of subsymmetric 784 graciliform element, GSC139149; 48, inner lateral view of truncatiform element, GSC139150; 785 49, inner lateral view of asymmetrical graciliform element, GSC139151.

787 Figure 9. Late Ordovician conodonts $\left(\mathrm{Sg}^{2}, \mathrm{Sg}^{1}, \mathrm{Sc}^{1}\right.$ and $\mathrm{Sc}^{0}$ represent grandiform with costa on 788 two sides, grandiform with costa on one side, compressiform with costa on one side, and 789 compressiform without costa in the Pseudobelodina apparatus, respectively). 
790 791 792 793 794 795 796 797 798 799 800 801 802 803 804 805 806 807 808 809 810 811 812

1. Culumbodina cf. C.n. sp. X McCracken (×60); from SZ15-16-04, Amadjuak Formation; inner lateral view of adenticulate triangular element, GSC139152.

2-3. Culumbodina occidentalis Sweet from SZ15-15-03, Akpatok Formation; $2(\times 55)$, inner lateral views of bifid-cusp element, GSC139153; $3(\times 42)$, inner lateral view of adenticulate element, GSC139154.

4-6. Pseudobelodina adentata Sweet $(\times 80)$; from SZ14-09-02C, Amadjuak Formation; 4, inner lateral view of $\mathrm{Sg}^{2}$ element, GSC139155; 5 and 6, inner and outer lateral views of $\mathrm{Sc}^{1}$ element, $^{2}$ GSC139156.

7-10. Pseudobelodina? dispansa (Glenister) (×55) from SZ15-16-04, Akpatok Formation; 7 and 8, outer and inner lateral views of $\mathrm{Sc}^{0}$ element, GSC139157; 9 and 10, outer and inner lateral views of $\mathrm{Sg}^{2}$ element, GSC139158.

11-12. Plegagnathus nelsoni Ethington and Furnish $(\times 60)$ from SZ15-15-03, Akpatok Formation; 11, inner lateral view of nelsoniform element, GSC139159; 12, outer lateral view of plegagnathiform element, GSC139160.

13-15. Culumbodina penna Sweet $(\times 73)$ from SZ15-15-06, Akpatok Formation; 13, outer lateral view of L-shape element, GSC139161; 14, inner lateral view of L-shape element, GSC139162;

15, inner lateral view of subtriangular element, GSC139163.

16. Belodiniform element of Nowlan and McCracken (in Nowlan et al. 1988) $(\times 60)$ from SZ1515-03, Akpatok Formation; inner lateral view, GSC139164.

17. Plegagnathus dartoni (Stone and Furnish) $(\times 65)$ from SZ15-16-01, Akpatok Formation; inner lateral view of plegagnathiform element, GSC139165.

18-23. Pseudobelodina v. vulgaris Sweet $(\times 80)$; 18 and 19 from SZ15-15-01, Akpatok Formation, inner and outer lateral views of $\mathrm{Sg}^{2}$ element, GSC139166; 20 and 21 from SZ14-07- 
813 01C, Akpatok Formation, inner and outer lateral views of $\mathrm{Sg}^{1}$ element, GSC139167; 22 and 23

814 from SZ15-14-01, Amadjuak Formation, inner and outer lateral views of Sc ${ }^{1}$ element,

815 GSC139168.

816 24-27. Pseudobelodina quadrata Sweet ( $\times 65) ; 24$ and 25 from SZ15-15-01, Akpatok Formation,

817 inner and outer lateral views of $\mathrm{Sc}^{0}$ element, GSC139169; 26 and 27 from SZ15-14-01,

818 Amadjuak Formation, outer and inner lateral views of $\mathrm{Sg}^{1}$ element, GSC139170.

819 28-33. Pseudobelodina torta Sweet $(\times 65)$ from AZ15-16-05, Akpatok Formation; 28 and 29,

820 inner and outer lateral views of $\mathrm{Sc}^{2}$ element, GSC139171; 30 and 31, outer and inner lateral

821 views of $\mathrm{Sg}^{1}$ element, GSC139172; 32 and 33, outer and inner lateral views of $\mathrm{Sg}^{2}$ element,

822 GSC139173.

823 34-37. Paroistodus? nowlani Zhen, Webby and Barnes (×63) from SZ15-22-01, Akpatok

824 Formation; 34 and 35, inner lateral views of Sb-c element, GSC139174, GSC139175; 36, lateral

825 view of Sa element, GSC139176; 37, inner lateral view of M element, GSC139177.

826 38-42. Scabbardella sp. (×57) from SZ15-22-01, Akpatok Formation; 38, inner lateral view of

827 asymmetric element, GSC139178; 39 and 40, outer and lateral views of subsymmetric element,

828 GSC139179; 41 and 42, outer and inner lateral views of symmetric element, GSC139180.

829

830 Figure 10. Late Ordovician conodonts

831 1-5. Amorphognathus ordovicicus Branson and Mehl (×75, except for $1 \times 50)$ from SZ15-16-04,

832 Akpatok Formation; 1, upper view of Pa element, GSC139181; 2, lateral view of Sa element,

833 GSC139182; 3, outer lateral view of Pb element, GSC139183; 4, outer-posterior view of M

834 element, GSC139184; 5, inner lateral views of Sb-Sc element, GSC139185.

835 6-9. Phragmodus undatus Branson and Mehl $(\times 85)$ from SZ14-05A-02C, Amadjuak 
836 Formation; 6, outer lateral view of Pa element, GSC139186; 7, lateral view of S element,

837 GSC139187; 8, outer lateral view of Pb element, GSC139188; 9. 24. inner lateral view of $\mathrm{M}$

838 element, GSC139189.

839 10-15. Plectodina tenuis (Branson and Mehl) $(\times 60)$ from SSZ14-09A-02C, Amadjuak

840 Formation; 10, inner lateral view of Pa element, GSC139190; 11, inner lateral view of Sc

841 element, GSC139191; 12, inner-posterior view of M element, GSC139192; 13, posterior view of

842 Sb element, GSC139193; 14, posterior view of Sa element; GSC139194; 15, inner lateral view

843 of Pb element, GSC139195.

844 16-20. Periodon grandis (Ethington) (×85) from SZ14-02-02C, Amadjuak Formation; 16, inner

845 lateral views of Sc element, GSC139196; 17, inner lateral view of M element, GSC139197; 18,

846 inner lateral views of Sb element, GSC139198; 19, inner lateral view of P element, GSC139199;

84720 , lateral view of Sa element, GSC139200.

848 21-24. Rhipidognathus symmetricus Branson, Mehl and Branson $(\times 70)$ from SZ15-13-01 except

849 for 23 from SZ15-18-08, Foster Bay Formation; 21, inner lateral view of Pa element,

850 GSC319201; 22 and 23, posterior view of Sa element, GSC139202 and GSC139203; 24 inner

851 lateral view of $\mathrm{Pb}$ element, GSC139204.

852 25-26. Protopanderodus liripipus Kennedy, Barnes and Uyeno (×40) from SZ14-02A-02C,

853 Amadjuak Formation; 25, lateral view of scandodontiform element, GSC139205; 26, lateral view

854 of acontiodontiform element, GSC139206.

855 27-32. Oulodus velicuspis (Pulse and Sweet) (×55) from SZ15-14-02, Amadjuak Formation; 27,

856 posterior-lateral view of Pa element, GSC139207; 28, posterior view of Sb element, GSC139208;

85729 , posterior view of Sa element, GSC139209; 30, posterior-lateral view of Pb element, 
$858 \mathrm{GSC} 139210 ; 31$, inner lateral view of Sc element, GSC139211; 32, posterior-lateral view of M 859 element, GSC139212.

860 

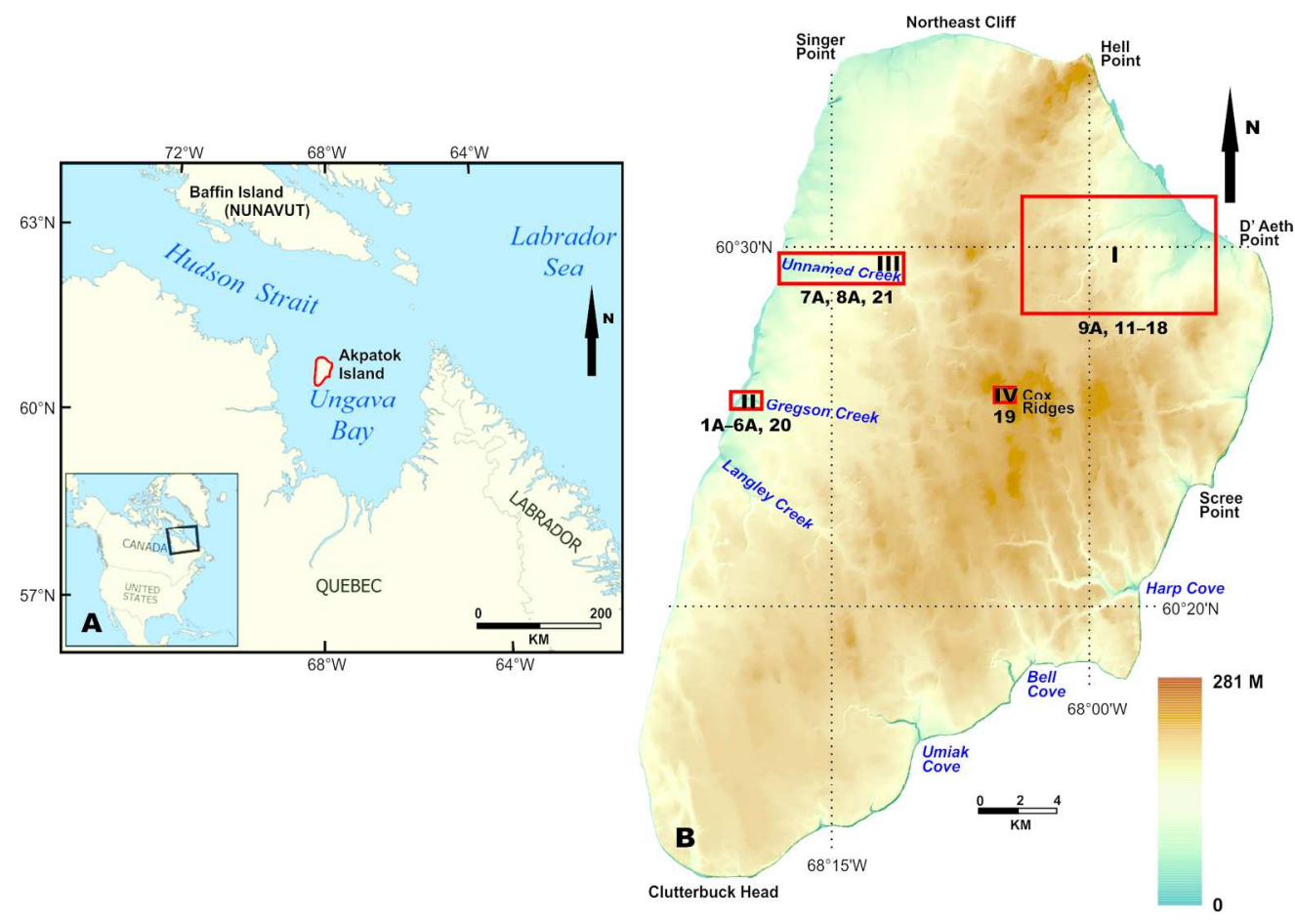

Figure 1

$172 \times 121 \mathrm{~mm}(300 \times 300$ DPI $)$ 


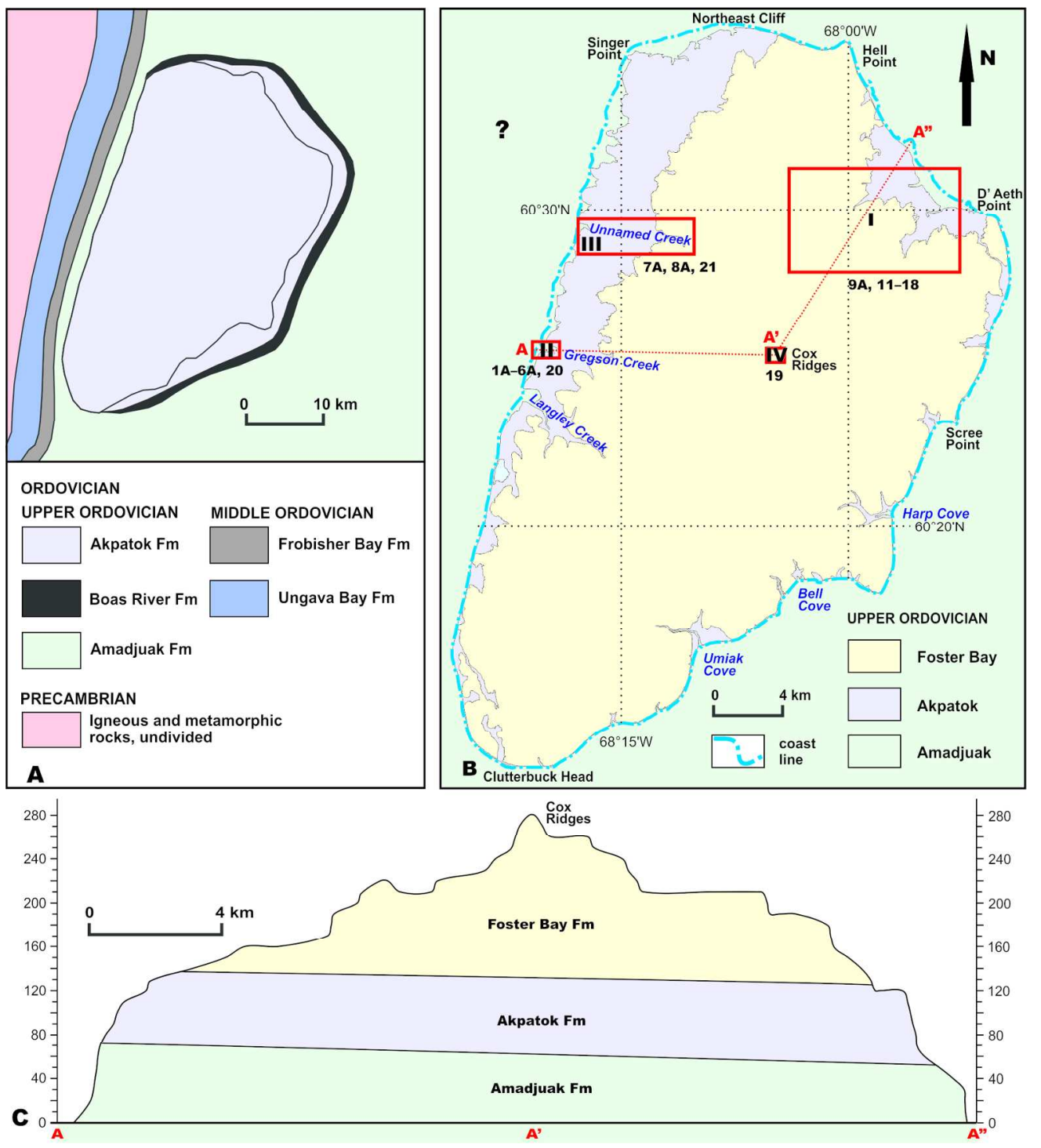

Figure 2

$162 \times 181 \mathrm{~mm}(300 \times 300 \mathrm{DPI})$ 


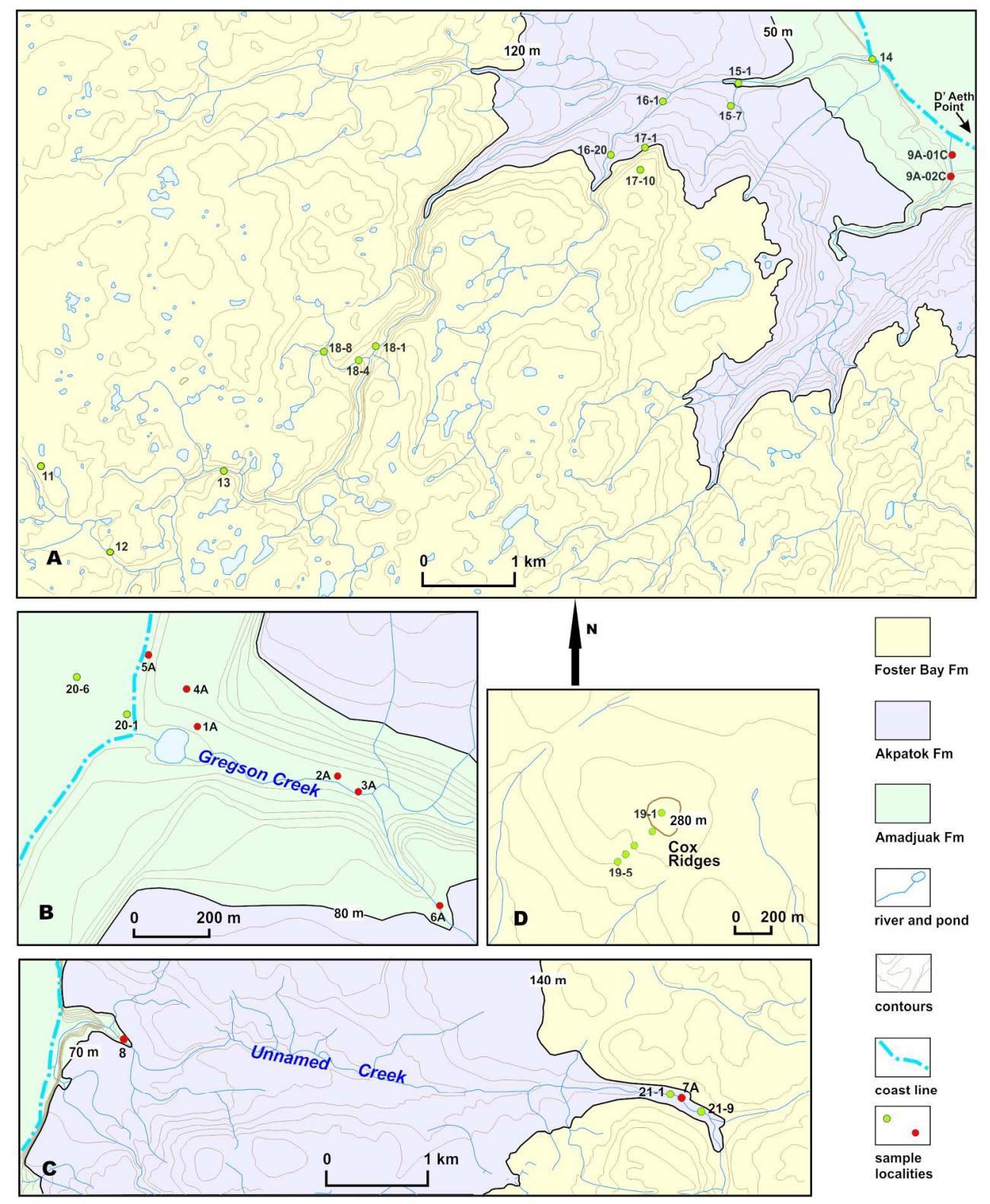

Figure 3

$175 \times 216 \mathrm{~mm}(300 \times 300 \mathrm{DPI})$ 


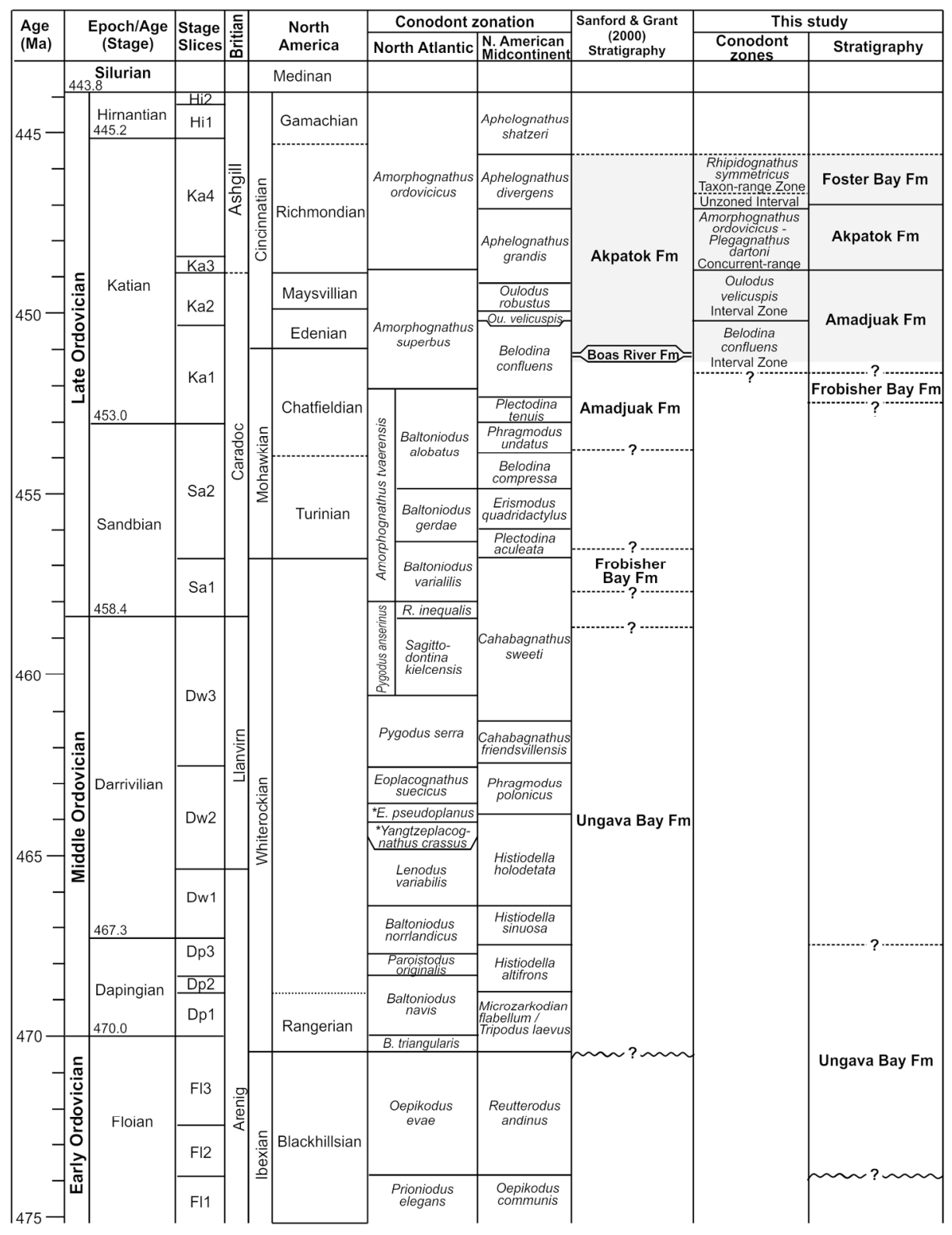

Figure 4

$150 \times 196 \mathrm{~mm}(300 \times 300 \mathrm{DPI})$ 


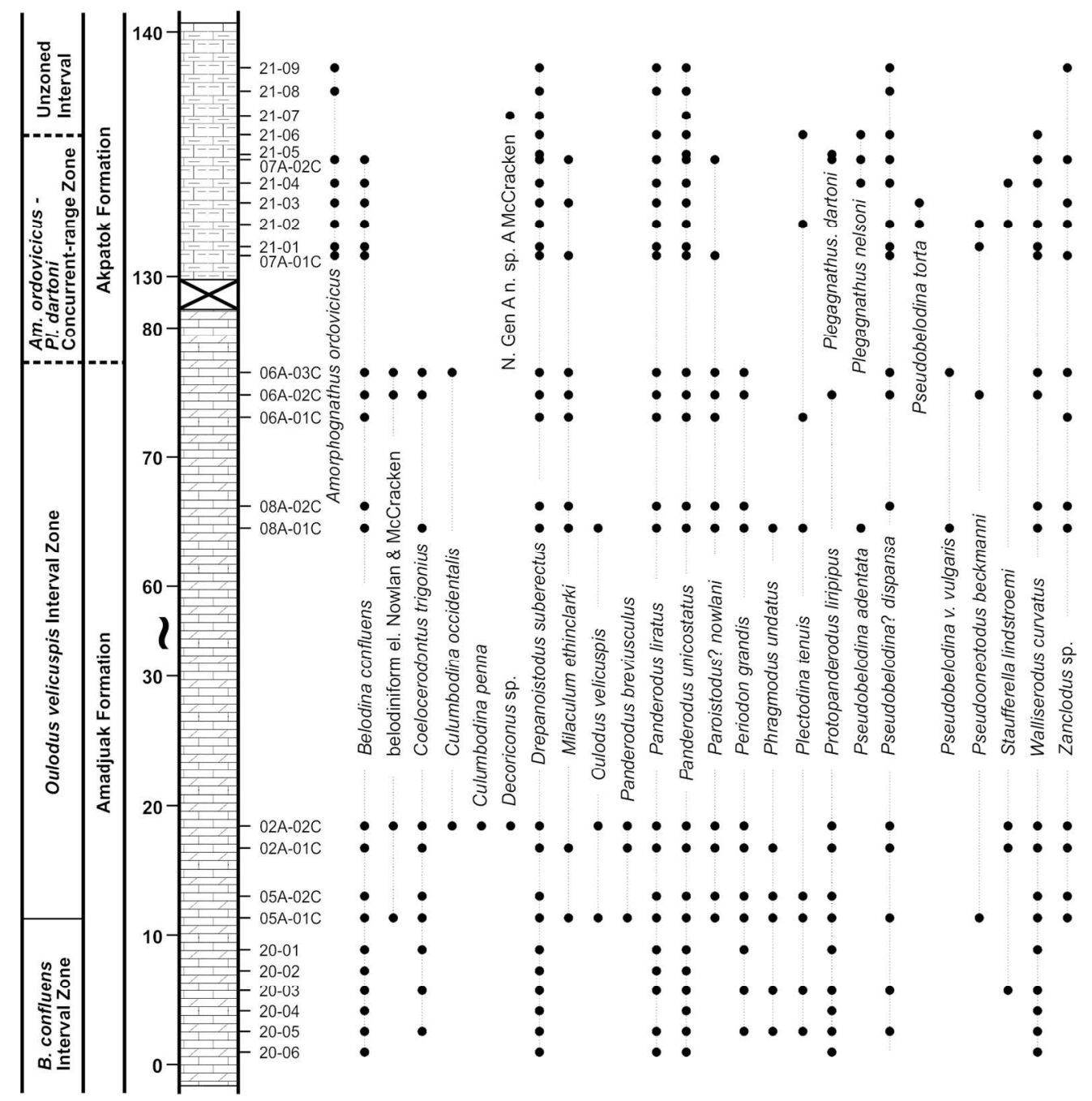

Figure 5

$142 \times 146 \mathrm{~mm}(300 \times 300$ DPI $)$ 


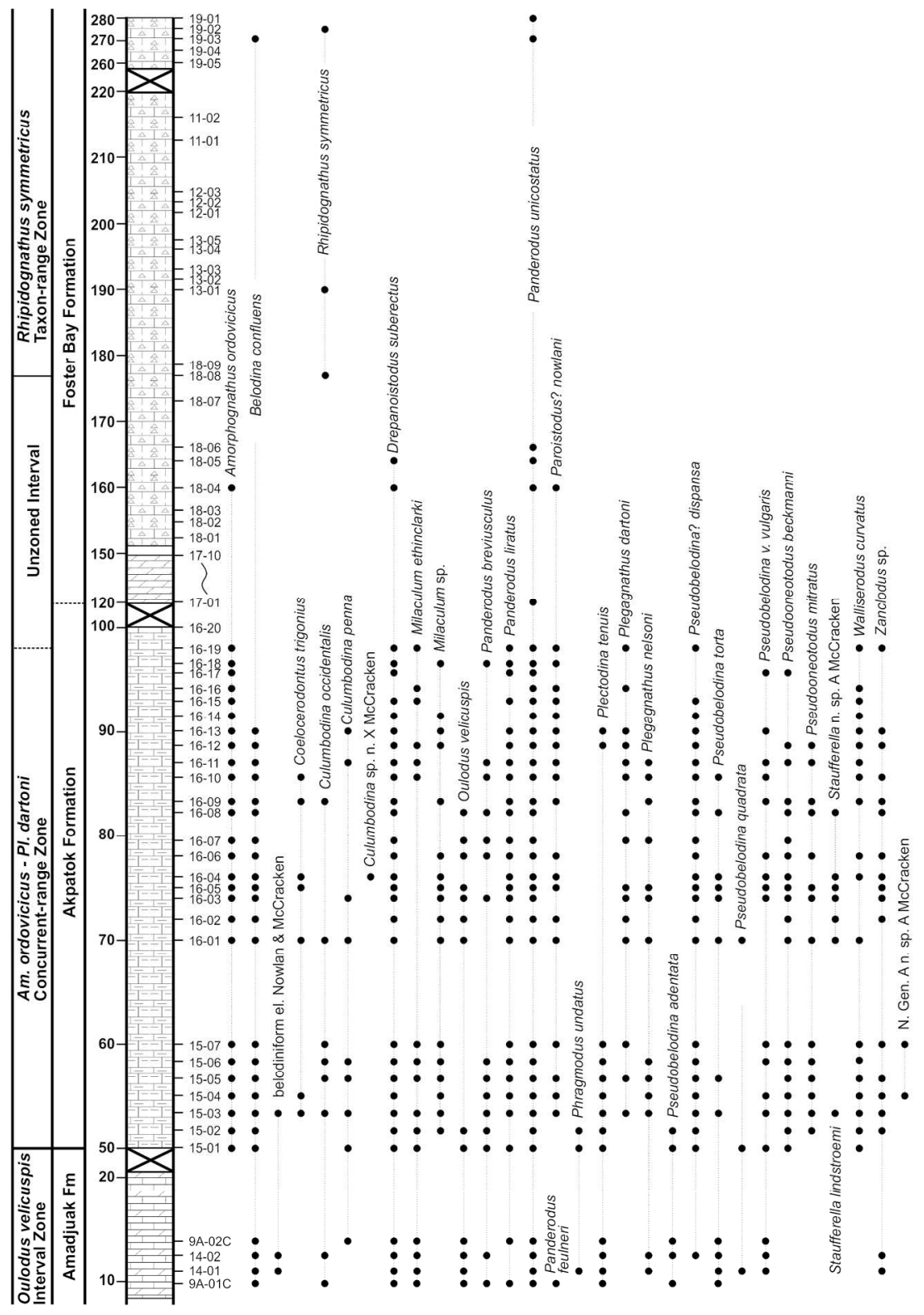

Figure 6

$181 \times 221 \mathrm{~mm}(300 \times 300$ DPI $)$ 


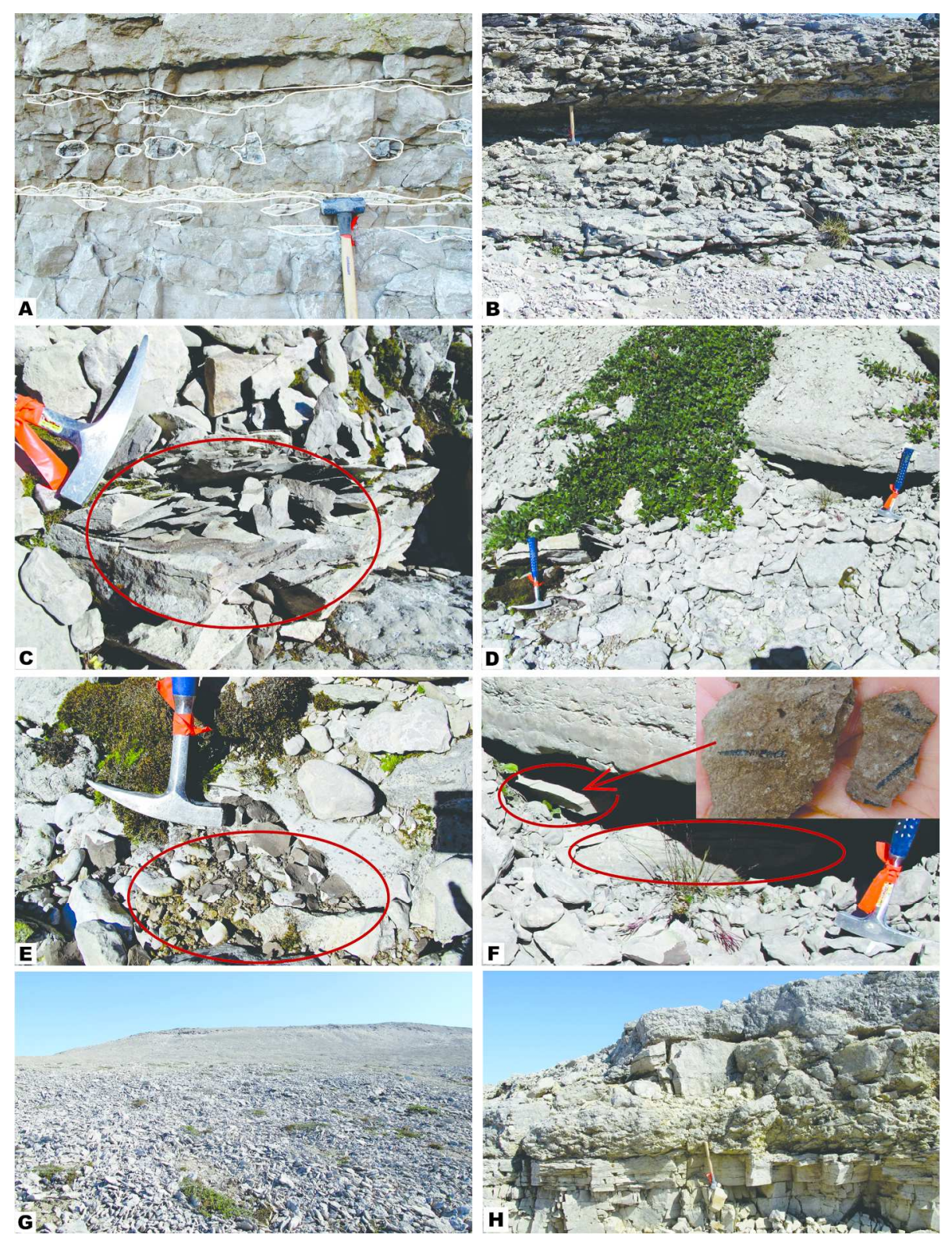

Figure 7

$174 \times 229 \mathrm{~mm}(300 \times 300 \mathrm{DPI})$ 


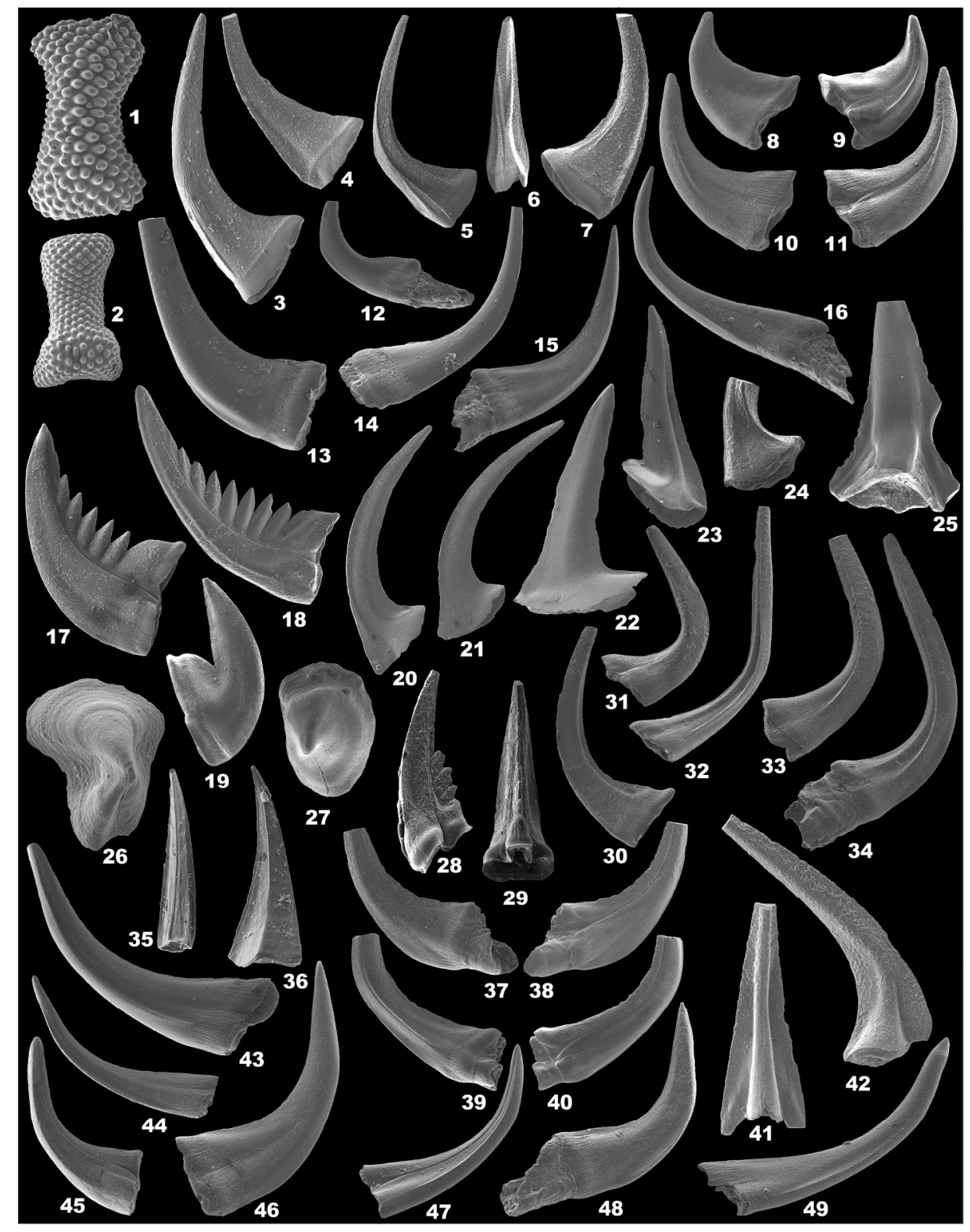

Figure 8

$171 \times 221 \mathrm{~mm}(300 \times 300$ DPI) 


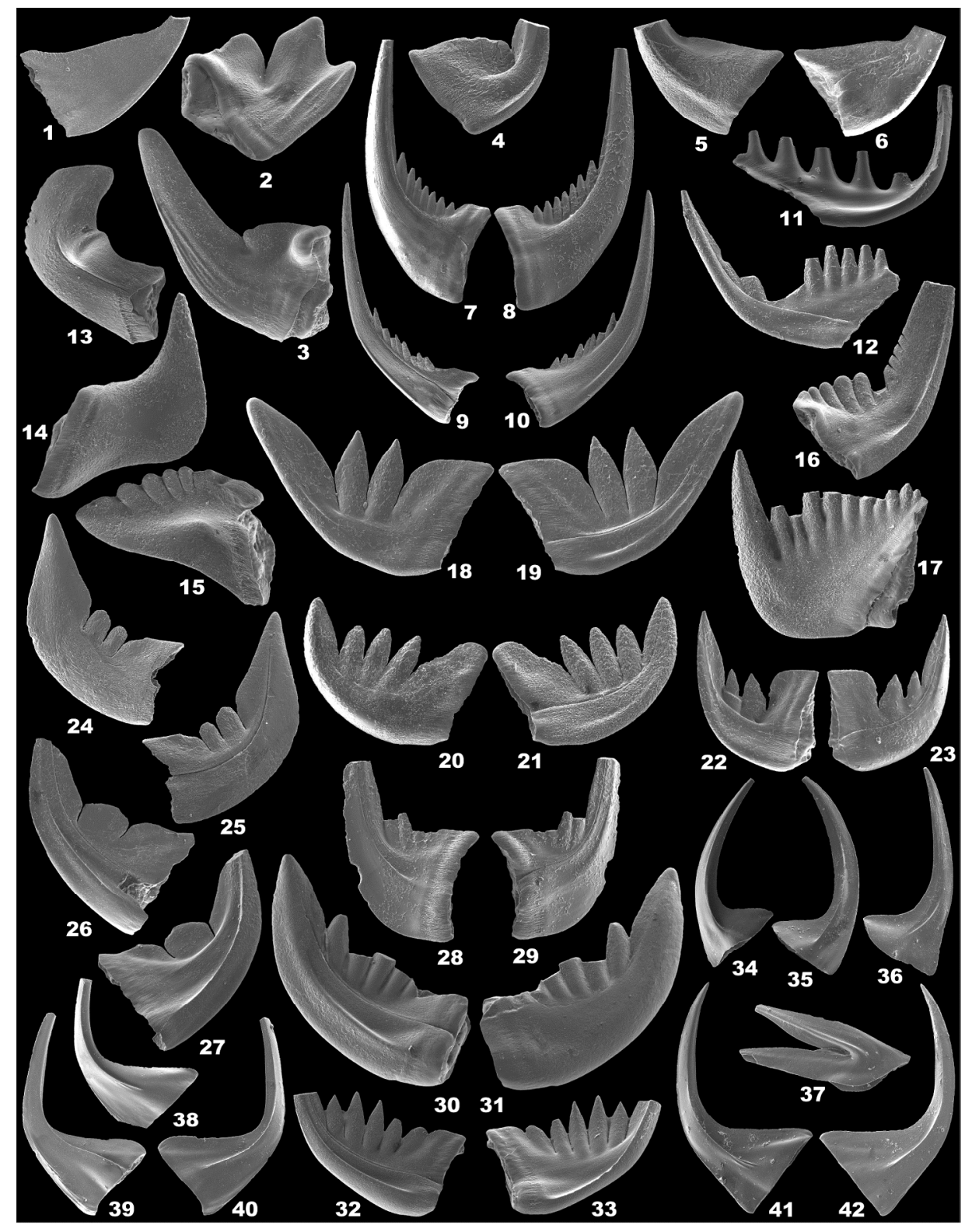

Figure 9

$171 \times 220 \mathrm{~mm}(300 \times 300$ DPI $)$ 


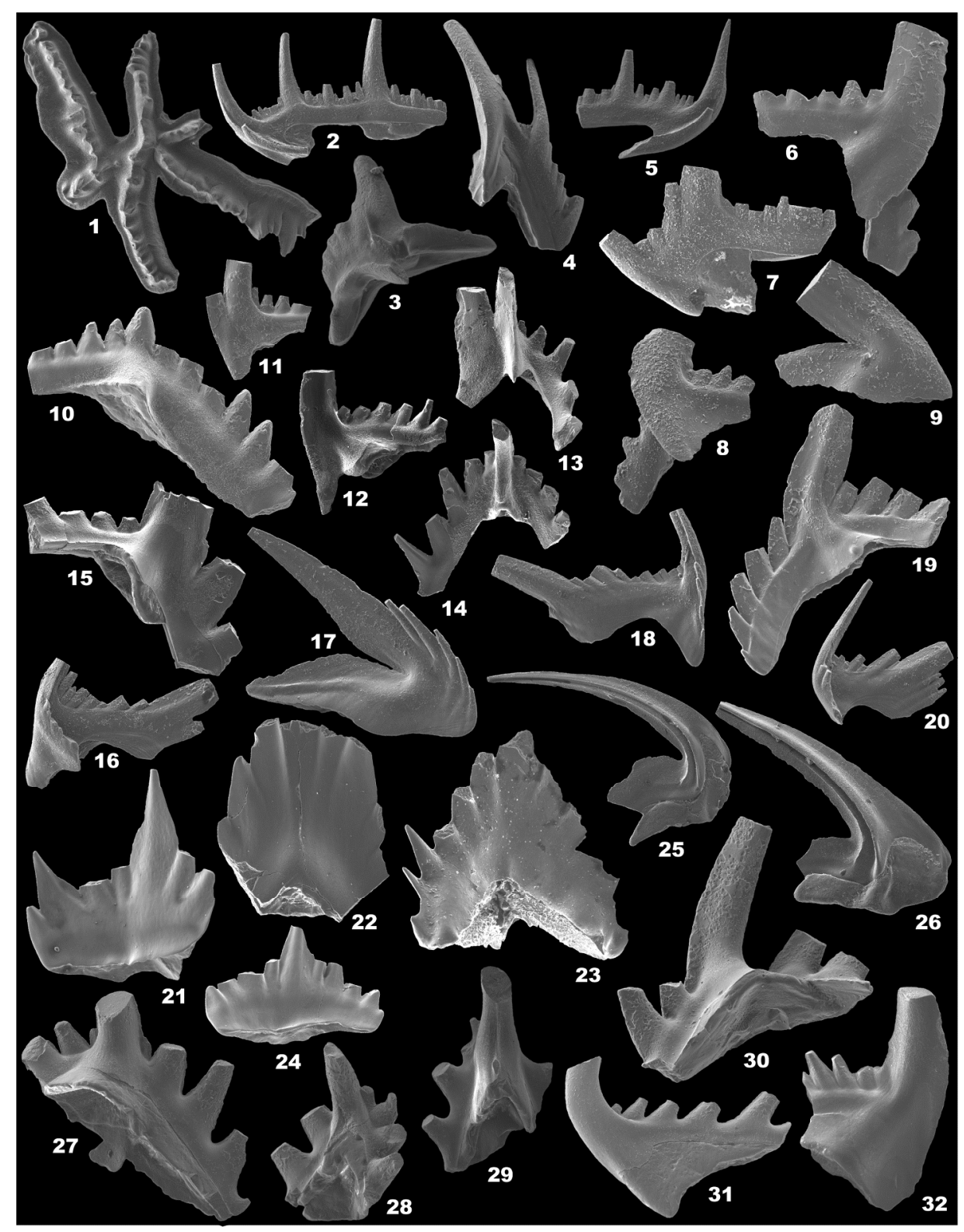

Figure 10

$171 \times 221 \mathrm{~mm}(300 \times 300$ DPI $)$ 
Table S1. Conodont numerical data for the samples collected in 2015

\begin{tabular}{|c|c|c|c|c|c|c|c|c|c|c|c|c|c|c|c|c|c|}
\hline Samples & $\begin{array}{l}N \\
N \\
N \\
N \\
N \\
N \\
\dot{1}\end{array}$ & 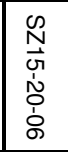 & $\begin{array}{l}N \\
N \\
0 \\
N \\
\tilde{O} \\
\dot{0} \\
0\end{array}$ & $\begin{array}{l}\infty \\
N \\
0 \\
N \\
N \\
0 \\
\dot{1}\end{array}$ & 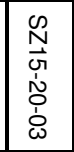 & $\begin{array}{l}N \\
N \\
N \\
N \\
N \\
0 \\
0 \\
N\end{array}$ & $\begin{array}{l}0 \\
N \\
N \\
N \\
N \\
0 \\
0 \\
0\end{array}$ & $\begin{array}{l}N \\
N \\
N \\
N \\
N \\
\dot{1} \\
\dot{1}\end{array}$ & $\begin{array}{l}N \\
N \\
0 N \\
N \\
\dot{N} \\
\dot{N}\end{array}$ & $\begin{array}{l}N \\
N \\
N \\
N \\
N \\
\dot{\omega} \\
\dot{\omega}\end{array}$ & $\begin{array}{l}N \\
N \\
N \\
N \\
N \\
\dot{1} \\
\dot{0}\end{array}$ & 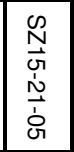 & $\begin{array}{l}N \\
N \\
0 \\
N \\
\\
\dot{8}\end{array}$ & 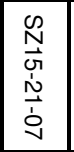 & $\begin{array}{l}\infty \\
N \\
0 \\
N \\
N \\
\dot{0} \\
\infty\end{array}$ & $\begin{array}{l}N \\
N \\
\mathbb{N} \\
N \\
\overrightarrow{1} \\
\dot{0}\end{array}$ & 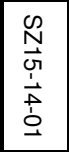 \\
\hline Areas (in Figures 1, 2 and 3) & \multicolumn{7}{|c|}{ II } & \multicolumn{9}{|c|}{ III } & \\
\hline Elevation (m) & $10-20$ & \multicolumn{6}{|c|}{$0-10$} & \multicolumn{9}{|c|}{$130-140$} & 10 \\
\hline Mass (g) & 2002 & 2005 & 2002 & 2005 & 2023 & 2009 & 2003 & 2001 & 2013 & 2002 & 2026 & 1995 & 2007 & 2005 & 2013 & 2023 & 2753 \\
\hline$\%$ Dissolution & 71.3 & 78.1 & 68.7 & 80.6 & 83 & 84.8 & 86.3 & 84.5 & 76.8 & 88.9 & 80.6 & 78 & 78.7 & 80 & 85.3 & 89.7 & 99.7 \\
\hline Amorphognathus ordovicicus & 10 & & & & & & & 17 & 29 & 18 & 15 & & & & 3 & 11 & \\
\hline Belodina confluens & 6 & 4 & 12 & 4 & 6 & 1 & 20 & 4 & 5 & 4 & 2 & & & & & & 9 \\
\hline belodiniform el. Nowlan \& McCracken & & & & & & & & & & & & & & & & & 1 \\
\hline Coelocerodontus trigonius & 35 & & 4 & & 3 & & 1 & & & & & & & & & & \\
\hline \multicolumn{18}{|l|}{ Cullumbodina occidentalis } \\
\hline \multicolumn{18}{|l|}{ Culumbodina penna } \\
\hline \multicolumn{18}{|l|}{ Culumbodina cf. C. sp. n. X MacCracken } \\
\hline Drepanoistodus suberectus & 74 & 8 & 9 & 4 & 8 & 1 & 12 & 7 & 8 & 5 & 1 & 3 & 4 & 1 & 1 & 5 & 54 \\
\hline Milaculum ethinclarki & & & & & & & & & & 1 & & & & & & & 10 \\
\hline \multicolumn{18}{|l|}{ Milaculum sp. $\mathrm{n}$. } \\
\hline Oulodus velicuspis & & & & & & & & & & & & & & & & & 10 \\
\hline \multicolumn{18}{|l|}{ Panderodus breviusculus } \\
\hline Panderodus feulneri & 253 & & rat & & & & & & & & & & & & & & \\
\hline Panderodus liratus & & 6 & 4 & to & 11 & 1 & 8 & 7 & 9 & 7 & 7 & & 8 & & 2 & 3 & 6 \\
\hline Panderodus unicostatus & & 59 & 112 & 49 & 52 & 18 & 81 & 163 & 239 & 148 & 91 & 25 & 72 & 15 & 14 & 51 & 415 \\
\hline Paroistodus? nowlani & 134 & & & & 0 & & & & & & & & & & & & \\
\hline Periodon grandis & & & 2 & & 3 & & 3 & & & & & & & & & & \\
\hline Phosphannulus universalis & & & 1 & & 1 & $\gamma$ & & & & & & & & & & & 6 \\
\hline Phragmodus undatus & & & 2 & & 4 & & & & & & & & & & & & 12 \\
\hline Plectodina tenuis & 5 & & 4 & & 4 & & & & 6 & & & & 1 & & & & 126 \\
\hline Plegagnathus dartoni & & & & & & & & & & & & 1 & & & & & \\
\hline Plegagnathus nelsoni & & & & & & & & & & & 1 & & 1 & & & & 2 \\
\hline Protopanderodus liripipus & & 1 & 2 & 6 & 4 & & 5 & & & & & & & & & & \\
\hline \multicolumn{18}{|l|}{ Pseudobelodina adentata } \\
\hline Pseudobelodina? dispensa & & & 3 & & 2 & & & 4 & 5 & & 2 & & 1 & & 1 & 1 & \\
\hline Pseudobelodina torta & & & & & & & & & 1 & 7 & & & & & & & 4 \\
\hline Pseudobelodina quatrata & & & & & & & & & & & & & & & & & 3 \\
\hline Pseudobelodina v. vulgaris & & & & & & & & & & & & & & & & & 1 \\
\hline Pseudooneotodus beckmanni & 3 & & & & & & & 2 & 3 & & & & & & & & \\
\hline \multicolumn{18}{|l|}{ Pseudooneotodus mitratus } \\
\hline \multicolumn{18}{|l|}{ Rhipidognathus symmetricus } \\
\hline Scabbardella sp. & 55 & & & & & & & & & & & & & & & & \\
\hline Staufferella lindstroemi & & & & & $1 ?$ & & & & 1 & & 1 & & & & & & \\
\hline \multicolumn{18}{|l|}{ Staufferella n. sp. A of McCracken } \\
\hline Walliserodus curvatus & & 2 & 4 & 1 & 3 & & 2 & 1 & 1 & & 3 & & 3 & & & & 2 \\
\hline Zanclodus sp. & & & & & & & & & 3 & 3 & & & & & & 2 & \\
\hline N. Gen. A n. sp. A MacCracken & & & & & & & & & & & & & & 1 & & & \\
\hline
\end{tabular}

NOTE: Sample numbers in grey-colored cells represent barren samples; sample numbers with red font repesent rubble samples. 


\begin{tabular}{|c|c|c|c|c|c|c|c|c|c|c|c|c|c|c|c|c|c|c|c|c|c|c|c|c|c|}
\hline 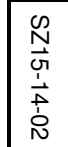 & $\begin{array}{c}\infty \\
\mathbb{N} \\
\frac{1}{N} \\
\frac{1}{1} \\
0\end{array}$ & $\begin{array}{l}N \\
N \\
\mathbb{N} \\
\frac{1}{N} \\
\dot{N}\end{array}$ & $\begin{array}{l}N \\
N \\
\frac{N}{c} \\
\frac{1}{N} \\
\dot{\omega}\end{array}$ & 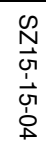 & 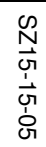 & $\begin{array}{l}N \\
\frac{N}{N} \\
\frac{1}{N} \\
\dot{\sigma}\end{array}$ & $\begin{array}{c}N \\
\mathbb{N} \\
\frac{1}{v} \\
\dot{v}\end{array}$ & $\begin{array}{l}\infty \\
\mathbb{N} \\
\bar{c} \\
\dot{\sigma} \\
\dot{0} \\
0\end{array}$ & 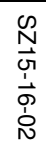 & $\begin{array}{l}\infty \\
N \\
\frac{N}{c} \\
\dot{a} \\
\dot{0} \\
\dot{\omega}\end{array}$ & $\begin{array}{l}\infty \\
N \\
\text { cr } \\
\frac{1}{\sigma} \\
\dot{1} \\
\dot{1}\end{array}$ & $\begin{array}{l}\text { N } \\
\text { cr } \\
\dot{1} \\
\dot{1} \\
\dot{0}\end{array}$ & 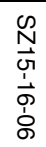 & $\begin{array}{l}\infty \\
N \\
\frac{N}{i} \\
\dot{0} \\
\dot{j}\end{array}$ & $\begin{array}{l}\infty \\
N \\
\text { ci } \\
\dot{1} \\
\dot{1} \\
\dot{\infty}\end{array}$ & $\begin{array}{l}N \\
N \\
\text { v } \\
\dot{1} \\
\dot{1} \\
\dot{0}\end{array}$ & $\begin{array}{l}N \\
N \\
\mathbb{N} \\
\dot{1} \\
\dot{1} \\
\dot{0}\end{array}$ & 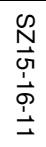 & $\begin{array}{l}N \\
\frac{N}{0} \\
\frac{1}{0} \\
\frac{1}{N}\end{array}$ & $\begin{array}{l}N \\
N \\
\vec{v} \\
\frac{1}{\omega} \\
\frac{1}{\omega}\end{array}$ & $\begin{array}{l}N \\
N \\
\frac{N}{N} \\
\frac{1}{0} \\
\frac{1}{\vec{D}}\end{array}$ & $\begin{array}{l}N \\
N \\
\frac{N}{N} \\
\frac{1}{0} \\
\frac{1}{v}\end{array}$ & $\begin{array}{l}N \\
N \\
\frac{N}{0} \\
\frac{1}{\sigma} \\
\frac{1}{\sigma}\end{array}$ & $\begin{array}{l}N \\
N \\
\frac{N}{0} \\
\dot{1} \\
\dot{1} \\
\dot{v}\end{array}$ & $\begin{array}{l}N \\
N \\
\frac{N}{1} \\
\dot{0} \\
\frac{1}{\infty}\end{array}$ \\
\hline
\end{tabular}

\begin{tabular}{|c|c|c|c|c|c|c|c|c|c|c|c|c|c|c|c|c|c|c|c|c|c|c|c|c|c|c|c|}
\hline \multirow{2}{*}{\begin{tabular}{|l}
.20 \\
2599 \\
\end{tabular}} & \multicolumn{8}{|c|}{$50-60$} & \multicolumn{19}{|c|}{$70-100$} \\
\hline & 2585 & 2666 & 2565 & 2575 & 2721 & 256 & & & 2588 & 2871 & 2796 & 2553 & $254 \varepsilon$ & 26 & & 2560 & 2551 & 2523 & 2573 & 2691 & 2502 & 2556 & 2465 & 2524 & 2677 & 2583 & 2566 \\
\hline 99.4 & 99 & 100 & 99.5 & 100 & 100 & 98. & & 9 & 99.1 & 99.5 & 99.9 & 96.6 & 99.5 & 95 & & 92.7 & 99.1 & 98.7 & 98.7 & 97.8 & 99.6 & 98.4 & 97.8 & 99 & 99.4 & 99.2 & 99.7 \\
\hline & 3 & 6 & 202 & 47 & 44 & 52 & & 0 & 79 & 76 & 185 & 158 & 162 & 5 & & 44 & 135 & 96 & 165 & 39 & 61 & 22 & 10 & 6 & 2 & 4 & 7 \\
\hline 7 & 8 & 3 & 41 & 7 & 9 & 14 & & 3 & 18 & 6 & 20 & 39 & 10 & 1 & & 1 & 18 & 12 & 15 & 12 & 7 & 2 & & & & & \\
\hline 1 & & & 1 & & & & & & & & & & & & & & & & & & & & & & & & \\
\hline & & & 2 & 3 & & & & & 2 & & & 1 & 1 & & & & & 5 & 1 & & & & & & & & \\
\hline 1 & & & 4 & & 1 & 1 & & 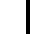 & 1 & & & & & & & & & 1 & & & & & & & & & \\
\hline & 1 & & 8 & & 1 & 6 & & & 5 & & 1 & & & & & & & & & $1 ?$ & & $1 ?$ & & & & & \\
\hline & & & & & & & & & & & & 1 & & & & & & & & & & & & & & & \\
\hline 37 & 50 & 67 & 84 & 26 & 46 & 34 & & 7 & 70 & 39 & 121 & 5 & 51 & 7 & & 4 & 12 & 5 & 4 & 16 & 13 & 10 & 1 & 5 & & 2 & 6 \\
\hline 14 & 40 & 32 & 7 & & 4 & 1 & & . & & & & & & & & & & & 5 & 33 & 24 & & & 1 & 1 & & \\
\hline & & 4 & 13 & 5 & 3 & 1 & & 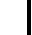 & 2 & 4 & 4 & 10 & 3 & 4 & & & & 3 & & & 13 & 1 & 3 & & & & 1 \\
\hline 13 & 5 & 6 & & & & & & & 22 & 27 & 84 & & 36 & 2 & & 12 & 11 & & & & & & & & & & \\
\hline 3 & 2 & 2 & 74 & 8 & 4 & 9 & & & & & 9 & & 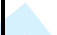 & 8 & & 5 & 16 & & 5 & 5 & & & & & & & 1 \\
\hline & 3 & 2 & 54 & 11 & 4 & 15 & & 5 & 17 & 13 & 6 & 12 & 5 & 6 & & 13 & 26 & 12 & 6 & 23 & 7 & 7 & & 4 & & 4 & 6 \\
\hline 257 & 367 & 116 & 836 & 327 & 168 & 205 & & & 305 & 203 & 541 & 594 & 267 & 8 & & 64 & 478 & 237 & 466 & 220 & 237 & 132 & 52 & 107 & 58 & 30 & 41 \\
\hline & & & 3 & 2 & 2 & & & 3 & 1 & 2 & & 91 & 1 & 1 & & & & 1 & 2 & 7 & 13 & 9 & 2 & 2 & 2 & & 1 \\
\hline 3 & 2 & 1 & 6 & 4 & & 2 & & ? & 6 & 2 & & 9 & 18 & 2 & & 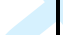 & 1 & 3 & 2 & 2 & 3 & 1 & & & & & \\
\hline & 20 & 10 & & & & & & & & & & & & & & 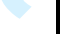 & & & & & & & & & & & \\
\hline 51 & 125 & 130 & 16 & 3 & 8 & 12 & ser & 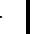 & & & & & & & & & & & & & 2 & 1 & & & & & \\
\hline & & & 3 & & 2 & & & 3 & 5 & 3 & 7 & & 4 & & & 1 & 6 & & 2 & 2 & 1 & 2 & & & 1 & & \\
\hline 1 & & & 5 & 4 & 3 & 4 & & & 1 & & 1 & & 1 & & & 2 & & 1 & 1 & 3 & & & & & & & \\
\hline 1 & 2 & 8 & & & & & & & & & & & & & & & & & & & & & & & & & \\
\hline 5 & 4 & 2 & 32 & 14 & 1 & 6 & & 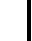 & 14 & 2 & 15 & 23 & 6 & 5 & & 3 & 9 & 3 & 14 & 8 & 5 & 4 & 1 & 1 & & & \\
\hline 2 & & & 1 & & 5 & & & & 2 & & 2 & 3 & 6 & & & & 2 & & 2 & & & & & & & & \\
\hline & 1 & & & & & & & & 1? & & & & & & & & & & & & & & & & & & \\
\hline 2 & 1 & & 3 & 1 & & 1 & . & & & & 4 & 1 & 1 & 2 & & & & 1 & 3 & 3 & & 1 & & & & 1 & \\
\hline & 6 & 6 & 5 & 7 & 5 & 7 & & & 16 & 8 & 10 & 6 & 3 & 6 & & 1 & 4 & 1 & & 1 & 4 & & & & & 1 & \\
\hline & & 1 & 4 & 3 & 3 & 3 & 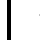 & & 7 & & 3 & & 2 & 1 & & & 2 & 1 & & 1 & 1 & & & & & & \\
\hline & & & & & & & & & & & & & & & & & & & & & & & & & & & \\
\hline & & & & & & & & & & & & & & & & & & & & & & & & & & & \\
\hline & & & 1 & & & & & & & & & & & & & & & & & & & & & & & & \\
\hline & & & & & & & & & 1 & 3 & 10 & 1 & 2 & & & & 1 & & & & & & & & & & \\
\hline 9 & 5 & 4 & 5 & 3 & 2 & 2 & 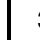 & & 3 & & & 12 & & 3 & & & & 1 & 2 & 2 & 2 & 6 & 2 & 1 & 1 & & \\
\hline & & 1 & 4 & 1 & 1 & & . & & & 1 & 2 & 12 & 5 & 2 & & & 8 & 6 & 14 & & 1 & 1 & & & & & \\
\hline & & & & 1 & & & 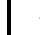 & & & & & & & & & & & & & & & & & & & & \\
\hline
\end{tabular}




\begin{tabular}{|c|c|c|c|c|c|c|c|c|c|c|c|c|c|c|c|c|c|c|c|c|c|c|c|c|c|}
\hline $\begin{array}{l}N \\
N \\
\frac{N}{1} \\
\overrightarrow{0} \\
\frac{1}{0}\end{array}$ & $\begin{array}{l}\infty \\
N \\
\text { N } \\
\dot{1} \\
\dot{1} \\
\text { Oे }\end{array}$ & $\begin{array}{l}N \\
N \\
\text { vN } \\
\stackrel{1}{N} \\
\dot{0}\end{array}$ & 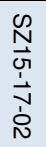 & 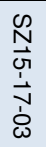 & 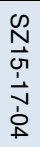 & 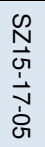 & 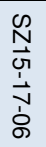 & $\begin{array}{l}0 \\
N \\
\frac{N}{N} \\
\dot{v} \\
\dot{v}\end{array}$ & 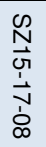 & $\begin{array}{l}\stackrel{N}{N} \\
\vec{U} \\
\stackrel{1}{\vec{v}} \\
\dot{0} \\
\dot{0}\end{array}$ & $\begin{array}{l}\frac{N}{N} \\
\frac{1}{0} \\
\frac{\dot{v}}{\vec{v}} \\
\frac{\dot{0}}{0}\end{array}$ & $\begin{array}{l}\stackrel{N}{N} \\
\stackrel{U}{0} \\
\dot{1} \\
0 \\
0 \\
0\end{array}$ & $\begin{array}{l}\infty \\
N \\
\text { UN } \\
\dot{1} \\
\infty \\
\dot{N} \\
N\end{array}$ & $\begin{array}{l}\stackrel{N}{N} \\
\stackrel{d}{v} \\
\dot{1} \\
\infty \\
\dot{\omega}\end{array}$ & $\begin{array}{l}\infty \\
N \\
\mathbb{N} \\
\dot{1} \\
\infty \\
\vdots \\
+\end{array}$ & $\begin{array}{l}D \\
N \\
\mathbb{N} \\
\dot{1} \\
\infty \\
\dot{0} \\
\text { cr }\end{array}$ & $\begin{array}{l}\infty \\
N \\
\text { v } \\
\dot{1} \\
\infty \\
\dot{\delta}\end{array}$ & 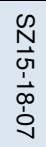 & $\begin{array}{l}\infty \\
N \\
\mathbb{N} \\
\dot{1} \\
\infty \\
\dot{0} \\
\infty\end{array}$ & $\begin{array}{l}N \\
N \\
0 \\
\dot{1} \\
\infty \\
\dot{0} \\
0\end{array}$ & $\begin{array}{l}N \\
N \\
\vec{N} \\
\frac{1}{\omega} \\
0 \\
0\end{array}$ & $\begin{array}{l}N \\
N \\
\mathbb{N} \\
\dot{1} \\
\dot{\omega} \\
\dot{N}\end{array}$ & $\begin{array}{l}N \\
N \\
\mathbb{N} \\
\frac{1}{\omega} \\
\dot{\omega} \\
\omega\end{array}$ & $\begin{array}{l}N \\
N \\
\mathbb{N} \\
\frac{1}{\omega} \\
\dot{1} \\
+\end{array}$ & $\begin{array}{l}N \\
N \\
\frac{N}{v} \\
\dot{1} \\
\dot{\omega} \\
\dot{c}\end{array}$ \\
\hline
\end{tabular}

\begin{tabular}{|c|c|c|c|c|c|c|c|c|c|c|c|c|c|c|c|c|c|c|c|c|c|c|c|c|c|}
\hline & & \multicolumn{10}{|c|}{$120-150$} & \multicolumn{9}{|c|}{$150-180$} & \multicolumn{5}{|c|}{$190-200$} \\
\hline 2570 & 2530 & 2594 & 2489 & 1997 & 2014 & 2005 & 1996 & 1995 & 1997 & 2035 & 2003 & 1998 & 2001 & 2002 & 2006 & 2007 & 2021 & 2000 & 1996 & 1998 & 2573 & 2745 & 2680 & 2581 & 2592 \\
\hline 88.8 & 100 & 99.6 & 99 & 9.2 .8 & 84.9 & 88.4 & 88.5 & 91 & 86.5 & 90 & 86 & 87.8 & 84 & 83.7 & 80.8 & 84.8 & 82 & 87.8 & 95 & 85.2 & 100 & 99.2 & 100 & 98.7 & 100 \\
\hline 17 & & & & & & & & & & & & & & & 4 & & & & & & & & & & \\
\hline & & & & & & & & & & & & & & & & & & & & & & & & & \\
\hline & & & & & & & & & & & & & & & & & & & & & & & & & \\
\hline & & & & & & & & & & & & & & & & & & & & & & & & & \\
\hline & & & & & & & & & & & & & & & & & & & & & & & & & \\
\hline & & & & & & & & & & & & & & & & & & & & & & & & & \\
\hline & & & & & & & & & & & & & & & & & & & & & & & & & \\
\hline 8 & & & & & & & & & & & & & & & 2 & 6 & & & & & & & & & \\
\hline 5 & & & & & & & & & & & & & & & & & & & & & & & & & \\
\hline
\end{tabular}

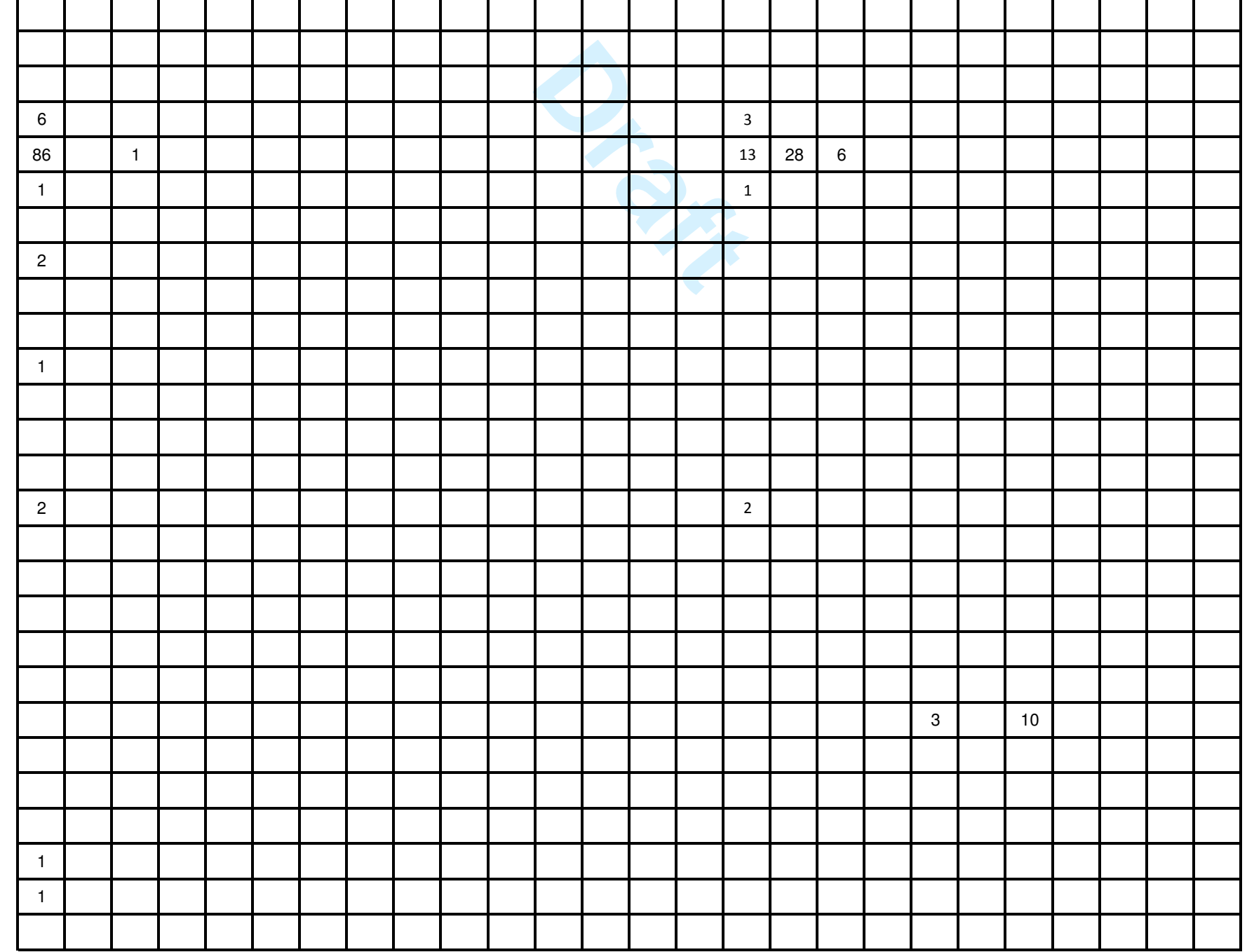




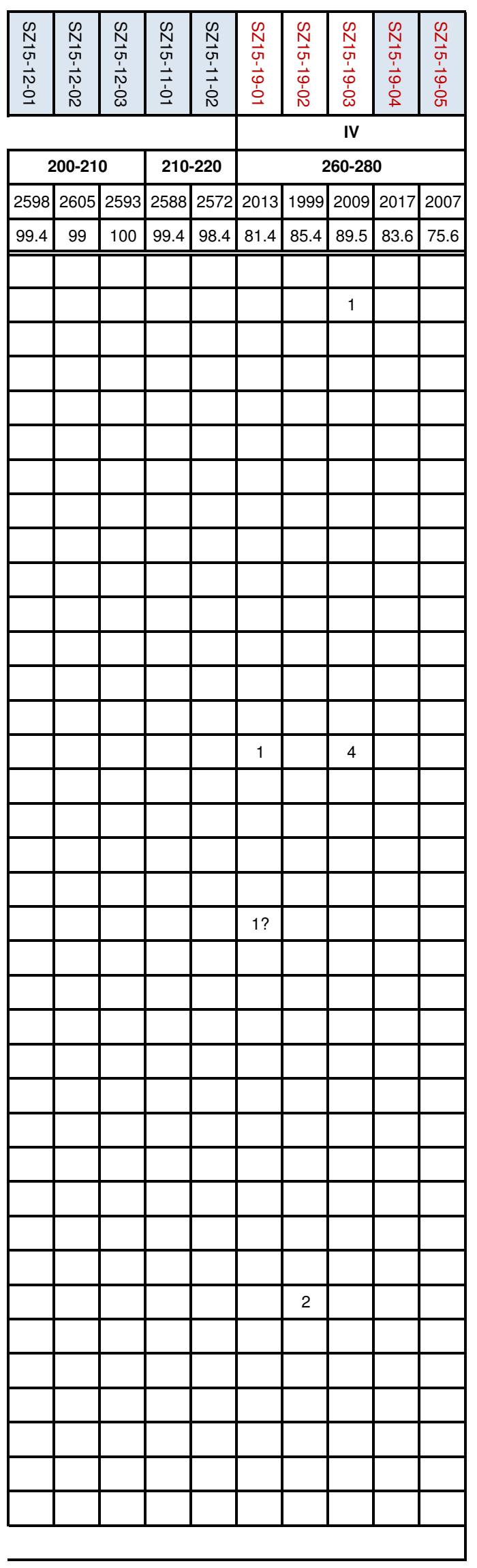


Table S2. Conodont numerical data for the samples collected in 2014

\begin{tabular}{|c|c|c|c|c|c|c|c|c|c|c|c|c|c|}
\hline Samples & 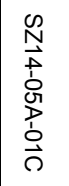 & $\begin{array}{l}N \\
N \\
\vec{A} \\
\dot{0} \\
\stackrel{M}{1} \\
\dot{0} \\
N \\
\tilde{N}\end{array}$ & 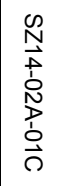 & 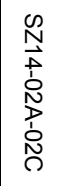 & 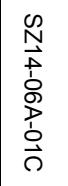 & $\begin{array}{l}\text { N } \\
N \\
\vec{A} \\
\dot{0} \\
D \\
\dot{P} \\
\hat{N} \\
0\end{array}$ & 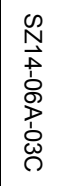 & 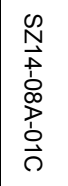 & 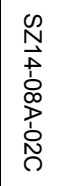 & 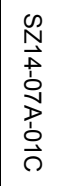 & 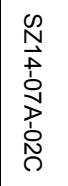 & $\begin{array}{l}\mathbb{N} \\
N \\
\stackrel{P}{0} \\
\dot{0} \\
0 \\
P \\
0 \\
\overrightarrow{0}\end{array}$ & 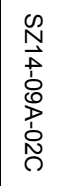 \\
\hline Areas (in Figures 1, 2 and 3) & \multicolumn{7}{|c|}{ II } & \multicolumn{4}{|c|}{ III } & \multicolumn{2}{|c|}{$\mathrm{I}$} \\
\hline Elevation (m) & \multicolumn{2}{|c|}{$10-20$} & \multicolumn{2}{|c|}{$10-20$} & \multicolumn{3}{|c|}{$70-80$} & \multicolumn{2}{|c|}{$60-70$} & \multicolumn{2}{|c|}{$130-140$} & \multicolumn{2}{|c|}{$10-20$} \\
\hline Mass (g) & 2707 & 2552 & 2647 & 2583 & 2620 & 2757 & 2744 & 2665 & 2577 & 2454 & 2479 & 2601 & 2657 \\
\hline$\%$ Dissolution & 93.9 & 95 & 97.6 & 97.1 & 97.5 & 94.7 & 95.1 & 96.8 & 98.9 & 99.5 & 99.2 & 98.3 & 96.8 \\
\hline Amorphognathus ordovicicus & & & & & & & & & & 35 & 14 & & \\
\hline Belodina confluens & 57 & 46 & 86 & 23 & 1 & 20 & 27 & 37 & 12 & 4 & 6 & 8 & 4 \\
\hline belodiniform el. Nowlan \& McCracken & 1 & & & 1 & & 2 & 1 & & & & & & \\
\hline Coelocerodontus trigonius & 18 & 1 & 11 & 31 & & 3 & 11 & 16 & & & & & \\
\hline Cullumbodina occidentalis & & & & 2 & & & 1 & & & & & 2 & \\
\hline Culumbodina penna & & & & 1 & & & & & & & & & 1 \\
\hline Decoriconus sp. & & & & 5 & & & & & & & & & \\
\hline Drepanoistodus suberectus & 34 & 36 & 36 & 51 & 1 & 25 & 33 & 37 & 7 & 5 & 3 & 62 & 110 \\
\hline Milaculum ethinclarki & 3 & & 4 & & & 23 & 11 & 23 & 21 & 21 & 24 & 2 & 2 \\
\hline Oulodus velicuspis & 1 & & & 2 & & & & 7 & & & & 12 & 36 \\
\hline Panderodus breviusculus & 9 & & 16 & 3 & & & & & & & & 1 & \\
\hline Panderodus feulneri & & & 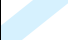 & 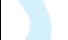 & & & & & & & & 4 & \\
\hline Panderodus liratus & 39 & 21 & 13 & 13 & 1 & 2 & 5 & 19 & 3 & 16 & 7 & 4 & 4 \\
\hline Panderodus unicostatus & 662 & 365 & 568 & 423 & 53 & 214 & 461 & 542 & 131 & 194 & 171 & 293 & 166 \\
\hline Paroistodus? nowlani & 22 & 4 & 11 & 19 & 2 & 7 & 12 & 19 & 4 & 26 & 10 & & \\
\hline Periodon grandis & 26 & 463 & 4 & 373 & 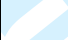 & 58 & 54 & 73 & 14 & & & & \\
\hline Phosphannulus universalis & 6 & 33 & 5 & 11 & 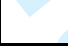 & 2 & 4 & 5 & 2 & 4 & & 2 & \\
\hline Phragmodus undatus & 9 & 19 & 9 & & & & & 3 & & & & & \\
\hline Plectodina tenuis & 2 & 1 & & & & 5 & & 11 & & & & 95 & 167 \\
\hline Plegagnathus dartoni & & & & & & & & & & & 1 & & \\
\hline Plegagnathus nelsoni & & & & & & & & & & & 5 & & \\
\hline Protopanderodus liripipus & 51 & 129 & 46 & 45 & & 1 & & & & & & & \\
\hline Pseudobelodina adentata & & & & & & & & 2 & & & & 5 & 6 \\
\hline Pseudobelodina? dispensa & 6 & & 2 & 4 & & 4 & 2 & & 2 & 8 & 7 & & \\
\hline Pseudobelodina torta & & & & & & & & & & & & 3 & 6 \\
\hline Pseudobelodina quatrata & & & & & & & & & & & & & \\
\hline Pseudobelodina v. vulgaris & & & & & & & 1 & 1 & & 6 & & & 3 \\
\hline Pseudooneotodus beckmanni & 1 & & & & & 1 & & & & 3 & 1 & & \\
\hline Rhipidognathus symmetricus & & & & & & & & & & & & & \\
\hline Staufferella lindstroemi & & & 2 & 2 & & & & & & & & & \\
\hline Staufferella n. sp. A of McCracken & & & & & & & & & & & & & \\
\hline Walliserodus curvatus & 54 & 23 & 53 & 12 & & 8 & 10 & 11 & 1 & 5 & 4 & & \\
\hline Zanclodus sp. & 2 & 12 & 7 & 7 & 2 & & 1 & 8 & & 3 & 3 & & \\
\hline
\end{tabular}

